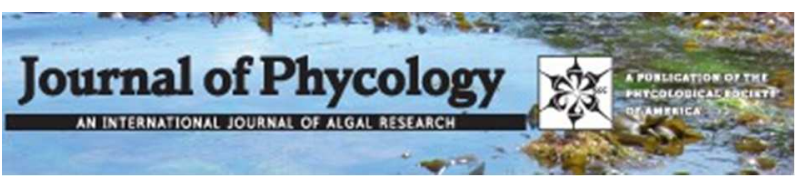

\title{
Genetic and morphological differentiation of Porphyra and Pyropia species (Bangiales, Rhodophyta) coexisting in a rocky intertidal in Central Chile
}

\begin{tabular}{|c|c|}
\hline Journal: & Journal of Phycology \\
\hline Manuscript ID & JPY-18-094-ART.R2 \\
\hline Manuscript Type: & Regular Article \\
\hline Date Submitted by the Author: & 30-Jul-2018 \\
\hline Complete List of Authors: & $\begin{array}{l}\text { Meynard, Andres; Universidad Andres Bello } \\
\text { Zapata, Javier; Universidad Andres Bello } \\
\text { Salas, Nicolas; Universidad Andres Bello } \\
\text { Betancourtt, Claudia; Universidad Andres Bello } \\
\text { Pérez-Lara, Gabriel; Universidad Andres Bello } \\
\text { Castañeda, Francisco; Universidad Andres Bello } \\
\text { Ramírez, Maria; Universidad Andres Bello } \\
\text { Bulboa Contador, Cristian; Universidad Andres Bello } \\
\text { Guillemin, Marie-Laure; Universidad Austral de Chile, Instituto de Ecología } \\
\text { y Evolución, Facultad de Ciencias } \\
\text { Contreras-Porcia, Loretto; Universidad Andrés Bello, Ecología y } \\
\text { Biodiversidad }\end{array}$ \\
\hline Keywords: & taxonomy, Macroalgae, Rhodophyta \\
\hline Alternate Keywords: & Intertidal distribution, Bangiales, $\mathrm{COI}$, rbcL, Chile \\
\hline \multicolumn{2}{|c|}{$\begin{array}{l}\text { Note: The following files were submitted by the author for peer review, but cannot be converted to } \\
\text { PDF. You must view these files (e.g. movies) online. }\end{array}$} \\
\hline $\begin{array}{l}\text { Figure 2.tif } \\
\text { Figure 6.tif } \\
\text { Figure 7.tif } \\
\text { Figure 8.tif } \\
\text { Figure 9.tif }\end{array}$ & \\
\hline
\end{tabular}




\section{Genetic and morphological differentiation of Porphyra and Pyropia species} (Bangiales, Rhodophyta) coexisting in a rocky intertidal in Central Chile Andrés Meynard, Javier Zapata, Nicolás Salas, Claudia Betancourtt, Gabriel Pérez-Lara, Francisco Castañeda

Departamento de Ecología y Biodiversidad, Facultad de Ciencias de la Vida, Universidad Andrés Bello, República 440, Santiago, Chile

Centro de Investigación Marina Quintay (CIMARQ), Facultad de Ciencias de la Vida, Universidad Andrés Bello, Quintay, Chile

\section{María Eliana Ramírez}

Departamento de Ecología y Biodiversidad, Facultad de Ciencias de la Vida, Universidad Andrés Bello, República 440, Santiago, Chile Museo Nacional de Historia Natural, Área Botánica, Casilla 787, Santiago, Chile Cristian Bulboa Contador

Departamento de Ecología y Biodiversidad, Facultad de Ciencias de la Vida, Universidad Andrés Bello, República 440, Santiago, Chile

\section{Marie-Laure Guillemin}

Instituto de Ciencias Ambientales y Evolutivas, Universidad Austral de Chile, Casilla 567 Valdivia, Chile CNRS, Sorbonne Universités, UPMC University Paris VI, PUC, UACH, UMI 3614, Evolutionary Biology and Ecology of Algae, Station Biologique de Roscoff, CS 90074, Place G. Teissier, 29680 Roscoff, France

Centro FONDAP de Investigación en Dinámica de Ecosistemas Marinos de Altas Latitudes (IDEAL) 
25 Departamento de Ecología y Biodiversidad, Facultad de Ciencias de la Vida, Universidad

26

27

$34{ }^{1}$ Date of submission and acceptance

$35 \quad 2$ Author for correspondence: e-mail: lorettocontreras@unab.cl
36

\section{$37 \quad$ Abstract}

Andrés Bello, República 440, Santiago, Chile

Centro de Investigación Marina Quintay (CIMARQ), Facultad de Ciencias de la Vida, Universidad Andrés Bello, Quintay, Chile

Center of Applied Ecology \& Sustainability (CAPES-UC), Pontificia Universidad Católica de Chile, Av. Libertador Bernardo O’Higgins 340, Santiago, Chile

A recent molecular taxonomic study along the Chilean coast $\left(18^{\circ} \mathrm{S}-53^{\circ} \mathrm{S}\right)$ described 18 candidate species of bladed Bangiales of which only two were formally described. Few studies focused on local genetic and morphological diversity of bladed Bangiales and attempted to determine their intertidal distribution in contrasting habitats; and none were performed in Chile. To delimit intertidal distributions of genetic species, 66 samples of bladed Bangiales were collected at Maitencillo $\left(32^{\circ} \mathrm{S}\right)$ in four zones: a rocky platform, a rocky wall, and two boulders zones surrounded by sandy and rocky bottoms, respectively. These samples were identified based on sequences of the mitochondrial COI and chloroplast $r b c \mathrm{~L}$ markers. We also collected 87 specimens for morphological 
47 characterization of the most common species, rapidly assessing their putative species

48 identity using newly developed species-diagnostic (PCR-RFLP) markers. Eight microscopic and two macroscopic morphological traits were measured. We described and

50

51

52

53

54

55

56

57

58

59

60

61 Key index words: Bangiales; taxonomy; $C O I$; $r b c \mathrm{~L}$; Chile; Intertidal distribution

62

63

64 polymorphism analyses; $r b c \mathrm{~L}$, large subunit ribulose bis-phosphate carboxylase/oxygenase. 65 66 67 68 named three out of four species that predominate in Maitencillo (including Pyropia orbicularis): Pyropia variabilis Zapata, Meynard, Ramírez, Contreras-Porcia, sp. nov., Porphyra luchensis Meynard, Ramírez, Contreras-Porcia sp. nov. and Porphyra longissima Meynard, Ramírez, Contreras-Porcia, sp. nov. With the exception of Po. longissima restricted to boulders surrounded by sandy bottom, and a morphotype of $P y$. variabilis restricted to rocky walls, the other species/morphotypes have overlapping intertidal distributions. Except for Po. longissima which is clearly differentiated morphologically (longest and thinnest blades), we conclude that morphology is not sufficient to differentiate bladed Bangiales. Our findings underscore the importance of refining our knowledge of intrinsic and environmental determinants on the distribution of bladed Bangiales.

\section{Key index words: Bangiales; taxonomy; COr; rbcL; Chile; Intertidal distribution} Abbreviations: COI, cytochrome oxidase I; ML, Maximum Likelihood; PCA, Principal Component Analysis; PCR-RFLP, polymerase chain reaction restriction fragment length 
Prior to the last decade, all foliose Bangiales have been classified under the genus Porphyra sensu lato (Blouin et al. 2011, Sutherland et al. 2011). Nevertheless, classical taxonomic methods, based mainly on morphological and life history traits, were shown to be highly misleading in this order (Sutherland et al. 2011). Indeed, with the advent of molecular phylogenies, several cryptic genera of foliose Bangiales were discovered and various classical genera were redefined (Sutherland et al. 2011, Sánchez et al. 2014, 2015, Yang et al. 2018). The existence of nine genera of bladed Bangiales was then proposed based on these molecular studies: Boreophyllum S.C Lindstrom N. Kikuchi, M. Miyata et Neefus, Clymene WA Nelson, Fuscifolium S.C Lindstrom, Miuraea N. Kikuchi, S. Arai, G. Yoshida, J.A. Shin et M. Miyata, Lysithea WA Nelson, Porphyra C. Agardh, Pyropia J. Agardh, Wildemania De Toni and Neothemis A.Sánchez, A.Vergés, C.Peteiro, J.Sutherland \& J.Brodie. Of particular note, most of the "nori" species cultivated in Asia nowadays belong to the genus Pyropia (Sutherland et al. 2011, Zuccarello 2011). At the genus level, the delimitation of species was undertaken recently using molecular tools, an advent that has redefined the frontiers of former taxa over the last ten years (e.g. Broom et al. 2002, Brodie et al. 2007, Neefus et al. 2008, Nelson et al. 2013, Guillemin et al. 2016, Dumilag et al. 2016, Reddy et al. 2018, Yang et al. 2018). A high level of cryptic genetic diversity was found within the two genera Porphyra and Pyropia (Brodie et al. 2007, Niwa et al. 2009, Broom et al. 2010, Lindstrom et al. 2015, Guillemin et al. 2016, Koh et al. 2018, Reddy et al. 2018, Yang et al. 2018). According to Zuccarello (2011), the discovery of these new taxa, that cannot be identified based on morphology, could drive field ecology studies to misleaded conclusions and impair our understanding of the evolutionary processes that generated this diversity. Hence, to aid in the rapid, cheap and reliable identification of some 
94 Asiatic bladed Bangiales, a number of studies carried by Niwa and collaborators (Teasdale 95 et al. 2002, 2005, 2009, 2010a, b, and 2014, Niwa \& Aruga 2006) developed molecular markers based on polymerase chain reaction restriction fragment length polymorphism (PCR-RFLP) analyses of nuclear and cytoplasmic genes.

Considering the economical, biotechnological, ecophysiological and evolutionary research potentials of species of bladed Bangiales, there is clearly a need to better define their taxonomic frontiers (Hurd et al. 2014). Moreover, this new appraisal of the taxonomic and biochemical diversity within the Bangiales could also unveil ecological patterns unseen under the old paradigm of identification based exclusively on morphology. Contradictory results have been published concerning intertidal zonation or habitat partitioning of Porphyra and Pyropia species living in sympatry (see, for example, West et al. 2005, for a positive answer, and Schweikert et al. 2012, for a negative one). Nevertheless, studies in other groups of red and brown algae showed that non-random small-scale distribution patterns occur locally between related algal species (e.g. Billard et al. 2010, Couceiro et al. 2015, Muangmai et al. 2016, Montecinos et al. 2017).

In Chile, a recent study using molecular methods and samples spanning most of the coast $\left(18^{\circ} \mathrm{S}-53^{\circ} \mathrm{S}\right)$, identified 18 species of bladed Bangiales belonging to the genus Porphyra, Pyropia, Fuscifolium and Wildemania (Guillemin et al. 2016). Of the 18 species encountered in Chile only two are named and were characterized morphologically (Ramírez et al. 2014, Guillemin et al. 2016). A group of closely related species (namely Pyropia sp. CHJ, Pyropia sp. CHK and Pyropia orbicularis Ramírez, Contreras-Porcia \& Guillemin (Ramírez et al. 2014, Guillemin et al. 2016) co-occur in central Chile. Pyropia orbicularis and Pyropia sp CHK were even observed in sympatry in the locality of Maitencillo. It is well known that adaptation to different ecological micro-niches could facilitate the 
118

119

120

121

122

123

124

125

126

127

128

129

130

131

132

133

134

135

136

137

138

139

140

141

coexistence of closely by related species in the same locality (Billard et al. 2010,

Muangmai et al. 2016), but differences in intertidal zonation or habitat between Pyropia sp.

CHJ, Pyropia sp. CHK and Pyropia orbicularis have not yet been studied.

The main aims of the present study was to (i) determine how many species of

bladed Bangiales are present in the locality of Maitencillo when using a sampling method

that takes into account the diversity of habitats present in the site, (ii) determine their

distribution along the tidal gradient and in the different habitats sampled, (iii) develop

simple and rapid species-diagnostic markers using polymerase chain reaction restriction

fragment length polymorphism (PCR-RFLP) on $r b c \mathrm{~L}$ gene amplicons for the

discrimination of these bladed Bangiales species, and (iv) describe the unnamed species

living at the study site using a combination of molecular tools and statistical analyses of morphological characters.

MATERIALS AND METHODS

Sampling of foliose Bangiales in Maitencillo beach

Sampling was performed in the rocky intertidal shore of Maitencillo, Valparaíso $\left(32^{\circ} 39^{\prime} \mathrm{S}\right.$, $71^{\circ} 26^{\prime} \mathrm{W}$, Fig. S1). This site is characterized by a rocky platform that gently slopes into the sea with small areas characterized by boulders and small, but steep rocky walls. Foliose Bangiales are prevalent in the upper intertidal zone while Mazzaella laminaroides (Rhodophyta) dominate the middle intertidal (Betancourtt et al. 2018). The lower intertidal zone is characterized by a sandy bottom. Two sampling schemes were used during the study. First, to characterize species diversity and small-scale distribution in Maitencillo we sampled 66 specimens of bladed Bangiales from July to December 2013 and 2014 (i.e. 
142 winter-spring) in different intertidal zones and habitats. Sampling took place along three 143 transects extending $20 \mathrm{~m}$ from the upper to lower intertidal zone of the rocky platform.

144 Twenty-two specimens of Bangiales were sampled within three areas of 5-6 meters long 145 per 0.5 meters wide along each transect. These three areas were defined as upper, middle 146 and lower intertidal, respectively, according to animal and seaweed limits previously 147 described in central Chile (Hoffmann \& Santelices 1987). This sampling was completed by 148 seventeen samples taken from two quadrants of $0.5 \mathrm{~m}^{2}$ placed on a steep wall adjacent to 149 the upper intertidal zone; and by 24 samples taken from four quadrants of $0.5 \mathrm{~m}^{2}$ placed in 150 two boulder zones (two quadrats in each zone, 12 samples per boulder zone). The boulder 151 zones were located $150 \mathrm{~m}$ from the main transect. One was surrounded by rocky pools 152 while the other was surrounded by pools of sandy bottoms. Some representative samples 153 were chosen as voucher specimens that are housed in the herbarium of the National 154 Museum of Natural History, Chile, under the SGO herbarium numbering system (see 155 voucher numbers in Table S1; Museo Nacional de Historia Natural, herbarium code: SGO, 156 http://www.mnhn.cl). To study the morphology of the four-dominant species encountered

157 in Maitencillo (see below for more information about species determination), a second 158 sampling was performed from August to December 2014 (i.e. winter-spring) where 87 159 specimens of bladed Bangiales were sampled in different intertidal habitats.

162 DNA extraction. Total genomic DNA was extracted from dried algal tissue grounded in 163 liquid nitrogen following the protocol originally described by Saunders (1993), with 164 modifications by Faugeron et al. (2001). 
166

167

168

169

170

171

172

173

174

175

176

177

178

179

180

181

182

183

184

185

186

187

188

189

COI and $r b c \mathrm{~L}$ amplification and sequencing. A partial sequence of the COI was obtained using a newly defined forward primer COIF3 (5'-

AATTAGRATGGAAYTAGCKCAACC-3') and the GazR1 primer, following the amplification protocols of Saunders (2005). A partial sequence of the $r b c \mathrm{~L}$ was obtained using the primers F-rbcL and R-rbcS (Hommersand et al. 1994), following the previously published amplification protocols (Hommersand et al. 1994, Fredericq and López-Bautista 2003). All PCR products were purified using UltraClean ${ }^{\mathrm{TM}}$ DNA Purification kits (MO BIO Laboratories, Carlsbad, CA, USA) and sequenced using the forward and reverse primers used for amplification by Macrogen Inc. (Seoul, South Korea). Sequences were aligned and edited using Bioedit (Hall 1999). Sixty-six specimens from the first sampling scheme and 24 from the second sampling scheme (for morphological analyses) were sequenced. During this study, 90 COI sequences (603 bp) and $46 r b c \mathrm{~L}$ sequences (873 bp) were obtained and deposited in GENBANK. Details about specimen collection information and GENBANK accession numbers are given in Table S1.

Species delimitation and phylogenetic relationship reconstruction. For the $r b c \mathrm{~L}$, in addition to the 46 sequences newly obtained from Maitencillo, 174 sequences of Chilean Bangiales specimens (including 20 sequences from Maitencillo, Guillemin et al. 2016) and 157 sequences retrieved from GENBANK were included in our data set. For the COI, in addition to the 90 sequences newly obtained (i.e. first and second sampling scheme) from Maitencillo, 159 sequences of Chilean Bangiales (including 20 from sequences from Maitencillo, Guillemin et al. 2016) as well as 39 sequences retrieved from GENBANK were included in our data set. The complete list of specimens used in molecular analyses is available in Tables S1 and S2. 
191 Guillemin et al. (2016), was examined using a maximum likelihood (ML) phylogenetic relationship reconstruction performed using IQ-TREE online server (Trifinopoulos et al. 2016). We selected the best-fit substitution model using the Akaike information criterion implemented in IQ-TREE (Nguyen et al. 2015, Trifinopoulos et al. 2016). The selected models were $\mathrm{TIM} 3+\mathrm{F}+\mathrm{G} 4$ and $\mathrm{TN}+\mathrm{F}+\mathrm{I}+\mathrm{G} 4$ for the COI (Pyropia and Porphyra, respectively) and TIM+I+G4 for the $r b c \mathrm{~L}$. Statistical support was estimated using 1,000 ultrafast bootstrap replicates (Nguyen et al. 2014). Minerva aenigmata W.A. Nelson (EU570053) and Dione arcuata W.A. Nelson (EU570052) were used as outgroups in the phylogenetic analysis of $r b c \mathrm{~L}$. For the COI (Sutherland et al. 2011), tree reconstructions were done separately for Pyropia and Porphyra species, using as outgroups Boreophylum 201 birdiae and Bangia fuscopurpurea, respectively, following Guillemin et al. (2016) and 202 Sutherland et al. (2011).

For each of the 90 specimens sequenced, affiliation to one of the 18 cryptic species observed in Chile (Guillemin et al. 2016) or to a newly encountered species was determined using the ML tree reconstruction. For the more problematic groups of sequences (i.e. corresponding to the group of closely related species Pyropia sp. CHJ, Pyropia sp. CHK 207 and Pyropia orbicularis), we followed the grouping proposed by Guillemin et al. (2016) 208 and a COI phylogeographic network was reconstructed using the median-joining algorithm implemented in HapView version Beta (Salzburger et al. 2011). For Pyropia sp. CHJ, 210 Pyropia sp. CHK and Pyropia orbicularis, we calculated mean genetic distances within211 and between-species for the COI in Mega6 (Tamura et al. 2013). Distances were calculated 212 using the Maximum Composite Likelihood method and variation rate among sites was 213 modeled with a gamma distribution; codon positions included were $1 \mathrm{st}+2 \mathrm{nd}+3 \mathrm{rd}$. 
215 Development of PCR-RFLP to rapidly assess putative species identity of Maitencillo foliose

216 Bangiales

217 Using the 44 sequences of $r b c \mathrm{~L}$ available for the four more common species of foliose

218 Bangiales encountered in Maintecillo (this study, Ramírez et al. 2014, Guillemin et al.

2192016 , see results for more information), we developed a method of species identification

220 using polymerase chain reaction restriction fragment length polymorphism analyses (PCR-

221 RFLP) of plastid DNA.

222 Differences in pattern of restriction digestion between species were examined in-

223 silico using the program Webcutter 2.0 (http://rna.lundberg.gu.se/cutter2/copyright 1997

224 Max Heiman). Amplification protocol of the $r b c \mathrm{~L}$ used in the PCR-RFLP analyses was the 225 same as described above. Nonetheless, PCRs were done using a different forward primer

226 than previously mentioned. Our newly developed primer $r b c \mathrm{~L}-\mathrm{Pyr}-\mathrm{F}$ (5'-

227 AGGTGTTGACCCGATTGAAG-3'), producing a longer fragment of $1230 \mathrm{bp}$ instead of

228873 bp, was used instead of F-rbcL (Hommersand et al. 1994) in the PCR mix. The

229 digestion of $0.5-1 \mu \mathrm{g}$ of $r b c \mathrm{~L}$ PCR product with $1.5 \mathrm{U}$ AfaI (Thermo Scientific, Pittsburgh, 230 PA) was performed following manufacturer instructions, with slight modifications. After

$23116 \mathrm{~h}$ at $37^{\circ} \mathrm{C}$, the reaction was stopped using a heat denaturation of $20 \mathrm{~min}$ at $65^{\circ} \mathrm{C}$. The

232 fragments obtained after digestion with AfaI were separated on a $2 \%$ TBE-agarose

233 electrophoresis. Because the $r b c$ L PCR-RFLP patterns obtained were extremely similar

234 between the two Pyropia species (see results for more details), a partial sequence of the

235 COI was obtained for 24 Pyropia samples using the same protocol as described above to

236 confirm the species identification obtained by PCR-RFLP. 


\section{Morphological measurements and statistical analyses}

For classical descriptions of foliose Bangiales species found at Maitencillo, the thallus shape, color, texture, and rhizoid position were described in 87 specimens previously identified at the species level using the newly developed PCR-RFLP method and COI sequences (see above). Microscopic observations of superficial and hand-cut transverse sections were used to establish tissue thickness and the number of cell layers, as well as to identify vegetative (generally at the thallus center) and reproductive structures (generally at the thallus border). More precisely, eight microscopic features of the gametophytic thallus were recorded, measuring three cells in three visual fields per photo, in a total of three photos per specimen. These morphological microscopic traits were the length and width of rhizoidal, vegetative, and zygotosporangial cells (surface views) and the thickness of vegetative and zygostosporangial lamina (hand-cut transverse sections). Moreover, the maximum length and maximum width of the thallus were also measured and considered in statistical analyses as macroscopic characteristics. Images were captured on an upright Leica ICC50 HD microscope (Wetzlar, Germany) using the Leica Application Suite Advanced Fluorescence EZ Imaging Software v.3.0 (Wetzlar, Germany).

To describe in multivariate space and search for morphological differences between foliose Bangiales species present at Maitencillo, principal component analysis (PCA) was applied to microscopic and macroscopic measurements using the software PAST specifying a variance-covariance matrix (Hammer et al. 2001). All statistical analyses were done with normalized data, using the Box-Cox transformation option (Box and Cox 1964) available in the statistical software R (R core team, 2017). Statistical differences between species for all traits were assessed through multivariate nested, permutational ANOVA using the Adonis function in R (Anderson 2001). The "plant" (i.e. individual) level was treated as nested 
262 factor within the main factor "species". Moreover, data for each morphological trait was

263 subjected to univariate post-hoc Tukey multiple comparisons in R (Abdi and Williams

264 2010) (after univariate ANOVA were done) to detect specific treatment differences

265 between species.

266

267

268

RESULTS

269

Genetic species present at Maitencillo. The Maximum Likelihood rooted tree for $r b c \mathrm{~L}$

271 sequences of Bangiales reconstructed with 46 new sequences obtained in this study (Fig. S2

272 a and b), reproduced the same general topology with almost the same support values as in

273 Fig. 1 of Guillemin et al. (2016). As shown by the Maximum Likelihood phylogenetic trees

274 reconstructed with $C O I$ sequences (Fig. $1 \mathrm{a}$ and $\mathrm{b}$ ) and $r b c \mathrm{~L}$ sequences (Fig. S2 a and b),

275 the 90 Bangiales samples from Maitencillo were assigned to 5 genetic species of bladed

276 Bangiales (i.e. represented as black triangles in the tree reconstructions). All five-delimited

277 species correspond to genetic entities previously identified by Guillemin et al. (2016).

278 Among these five species, four were dominant at Maitencillo: Pyropia orbicularis $(\mathrm{N}=$

279 14), Pyropia sp. CHK $(\mathrm{N}=47)$, Porphyra sp. CHE $(\mathrm{N}=16)$ and Porphyra sp. $\mathrm{CHC}(\mathrm{N}=$

280 12). Their habits are shown in Fig. 2. A fifth species, Porphyra sp. CHF, was also present

281 but in low frequency $(\mathrm{N}=2$, Table 1 and Table S1). Porphyra sp. CHE and Porphyra sp.

282 CHF were recovered as monophyletic sister groups both in the $r b c \mathrm{~L}$ and COI phylogenetic

283 trees (Fig. 1). Porphyra sp. CHC was also retrieved as a well-supported monophyletic

284 group in the two phylogenetic trees (Fig. 1 and Fig. S2). On the other hand, phylogenetic

285 trees were less clear concerning the number of distinct species that could be defined within 
286

287

288

289

290

291

292

293

294

295

296

297

298

299

300

301

302

303

304

305

306

307

308

309

the Pyropia orbicularis / Pyropia sp. CHK / Pyropia sp. CHJ species complex. Mean sequence divergence between species pairs was higher than 6\% between Pyropia

orbicularis and the other two species, whereas the distance between Pyropia sp. CHK and Pyropia sp. CHJ was 3.7\% (Table S3). All mean sequence divergences calculated within species were, at least, five times lower than the ones calculated between species (Table S3). Moreover, three groups of highly differentiated haplotypes (Pyropia orbicularis, Pyropia sp. CHK, and Pyropia sp. CHJ) were clearly shown by the reconstruction of the COI network for these recently diverged species (Supplementary material 4; Guillemin et al. 2016), all our newly acquired sequences being part of the Pyropia orbicularis and Pyropia sp. CHK groups (Fig. S3).

Microhabitats and intertidal distribution of genetic species. Species distribution of foliose Bangiales reported here is based on the information obtained during our first sampling scheme (66 specimens sequenced for the $C O I$ and 46 for $r b c \mathrm{~L}$ ). Foliose Bangiales were never observed in medium or low intertidal zones of the rocky platform (Table 1). From twenty-five foliose Bangiales sampled at the high intertidal zone on the rocky platform, 13 were assigned to Pyropia sp. CHK, nine to Porphyra sp. CHE, and three to Pyropia orbicularis (Table 1). On the rocky wall, 15 of the 17-sampled foliose Bangiales were identified as Pyropia sp. CHK, one as Porphyra sp. CHE, and one as Pyropia orbicularis (Table 1). In the boulder zone surrounded by rocky pools, six of the 12 samples were classified as Porphyra sp. CHE, four as Pyropia sp. CHK, and two as Porphyra sp. CHF (Table 1). In the boulder zone surrounded by pools of sandy bottom, all 12 samples were assigned to the genetic species Porphyra sp. CHC (Table 1). Fig. 2 shows the habits of the four dominant genetic species observed at Maitencillo beach. 
311 PCR-RFLP development and analysis for the $r b c \mathrm{~L}$. Among the $1230 \mathrm{bp}$ fragment amplified

312 by PCR for the $r b c \mathrm{~L}, 94$ polymorphic sites can be observed between aligned sequences of 313 the four Bangiales species dominating the intertidal of Maitencillo. The sequence positions 314 (i.e. variable sites) corresponding to the restriction site of AFA I in the rbcL-amplified 315 fragment are given in Table 2. As shown in Fig. 3, PCR-RFLP patterns of the $r b c \mathrm{~L}$ allowed 316 us to easily distinguish Porphyra sp. CHE from Porphyra sp. CHC and from the two 317 species of Pyropia. One very intense fragment located at approximately 900 bp was 318 observed in Porphyra sp. CHC, whereas two fragments of approximately 580 and $430 \mathrm{bp}$ 319 were the most visible and characteristic of Porphyra sp. CHE (Fig. 3). On the other hand, 320 only the presence of two fragments of approximately 600 and 700 bp in Pyropia 321 orbicularis and only one in Pyropia sp. CHK in the same size range, allowed 322 differentiating the two closes by Pyropia species (Fig. 3). Restriction patterns were 323 extremely similar between the two Pyropia species and generate doubts about species 324 determination for most samples of Pyropia. Indeed, as visible in Fig. 3, the two Pyropia 325 orbicularis bands of roughly similar size are not easily separated and generate a very 326 intense band/smear around 600-700 bp. This pattern can easily be confounded with Pyropia 327 sp. CHK for which PCR-RFLP products are overloaded. In order to complement our PCR328 RFLP analysis, 24 samples of Pyropia were then sequenced for the COI gene. Fifteen 329 samples corresponded to Pyropia sp. CHK and 9 to Pyropia orbicularis. Only these 24 330 sequenced individuals were used for morphological analyses when considering Pyropia 331 samples. 
333

334

335

336

337

Variation in morphological characters. Results of the PCA based on morphological characters are shown in Fig. 4. According to the eigenvalues, the cumulative proportion of the first two principal components explains $81 \%$ of the total variation in the data. Component 1 was represented mainly by thallus width and component 2 by thallus length. If we do not take into account the Pyropia sp. CHK data, specimens of Porphyra sp. CHE and Pyropia orbicularis would appear as discrete morphological clusters (data not shown). Nevertheless, both species show a high level of overlap with Pyropia sp. CHK in the PCA (Fig. 4). Conversely, Porphyra sp. CHC formed a discrete and distinctive morphological cluster in the PCA. Multivariate nested, permutational ANOVA (permanova) realized using the ten morphological traits measured, indicated that statistical differences exist between species and between plants (i.e. specimens) within species (Table 3). Indeed, post-hoc Tukey test for multiple comparisons identified significant differences $(p<0.05)$ between all pairs of species for four out of ten traits (Fig. 5). The largest values in length and width of the thallus were observed in Porphyra sp. CHC and Porphyra sp. CHE, respectively, while the thinnest and thickest reproductive laminae characterized Porphyra sp. CHC and Pyropia orbicularis, respectively. Within Porphyra, Porphyra sp. CHE showed bigger vegetative and zygotosporangial cells than Porphyra sp. CHC. Within Pyropia, Pyropia sp. CHK reached a larger width of vegetative cells and a smaller length and width of zygotosporangial cells than Pyropia orbicularis. Even if statistical analyses indicate that the width of vegetative cells is different between all 4 species, the boxplots for this trait in Fig. 5 show that the high variance observed in Pyropia sp. CHK overlap values measured in both Porphyra sp. CHC and Porphyra sp. CHE. 
356 Taxonomic treatment. Below we describe in detail three previously unnamed species: one 357 new species of Pyropia and two new species of Porphyra (See Fig. 2, Figs. 6-9, Table 4).

358 For the P. orbicularis description, see Fig. S4 and Ramírez et al. (2014).

359 1.- Porphyra luchensis Meynard, Ramírez, Contreras-Porcia sp. nov.

360 Description: The gametangial blades are semi-translucent, 39.0-156.0 $\mu \mathrm{m}$ thick in

361 transverse section, reniform, rhomboid to spear-shaped and asymmetrical when fully

362 extended, 5.0-22.0 cm long and 0.5-9.0 cm wide (Fig. 2A and Fig. 6A) with a loose,

363 wrinkled surface. Blade margins are spiny to undulated, often folded. Color green on the

364 center of the blade to reddish-brown on the margins. Blades are attached to rock substratum

365 by a basal rhizoidal holdfast. Thalli are monostromatic and monoecious. In sectional view,

366 blade vegetative portions are monostromatic and their thickness range from 68.0 to 156.0

$367 \mu \mathrm{m}$ (Fig. 6 C-D). Sexual regions of the thalli are monoecious, 39.0-136.0 $\mu \mathrm{m}$ thick in

368 sectional view (Fig. 6 E-H), with contiguous groups of cells forming either spermatangia or

369 zygotosporangia and divided into separate male and female sectors. Reproductive cells are

370 formed as continuous areas along the margins of the blade. The division formula of

371 spermatangia is $128(\mathrm{a} / 4, \mathrm{~b} / 4, \mathrm{c} / 8)$ whereas the division formula of zygotosporangia is 64

$372(\mathrm{a} / 2, \mathrm{~b} / 4, \mathrm{c} / 8)$ or $128(\mathrm{a} / 4, \mathrm{~b} / 4, \mathrm{c} / 8)($ Fig. 6 E-H). Table 4 summarizes the detailed

373 morphological features of 32 blades of Po. luchensis identified through molecular assisted

374 methods (i.e. PCR-RFLP).

375 Holotype: Voucher specimen = SGO168338, housed in the herbarium of the National

376 Museum of Natural History, Chile; sample code = CHE0027; gametophytic blade

377 (vegetative) collected from boulders in the upper intertidal zone from Maitencillo beach 


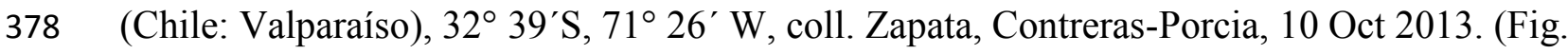

379 6A). GenBank accession numbers: COI, MH123945 and $r b c$ L, MH124031.

380 Distribution: Chile, from Atacama, Chañaral de Aceituno ( $\left.29^{\circ} 04^{\prime} \mathrm{S}, 71^{\circ} 29^{\prime} \mathrm{W}\right)$, to

381 Valparaíso, Maitencillo beach, $\left(32^{\circ} 39^{\prime} \mathrm{S}, 71^{\circ} 26^{\prime} \mathrm{W}\right)$.

382 Habitat: Thalli present year-round but more abundant in winter and spring, growing on 383 boulders surrounded by stony ground pools at low tide. The species is less abundant in 384 summer in the high and intermediate intertidal zones of rock platforms, where Pyropia 385 orbicularis is dominant.

386 Etymology: The specific epithet luchensis refers to the word "luche", a traditional name 387 used by fishermen communities along the Chilean coast and referring to the bladed 388 Bangiales harvested and sold for food consumption.

Comments: Porphyra luchensis Meynard, Ramírez, Contreras-Porcia sp. nov. corresponds to the genetic species Porphyra sp. CHE originally identified by Guillemin et al. (2016).
Description: The gametangial blades are semi-translucent, 36.0-122.0 $\mu \mathrm{m}$ thick in transverse section, linear to lanceolate and very long in comparison to their width, 16.0$50.0 \mathrm{~cm}$ long and $0.3-3.5 \mathrm{~cm}$ wide, and having a soft, relatively mucilaginous and flexible surface (Fig. 2B, and Fig. 7A). Blade margins are entire to sinuate. Color rosy pink to brown. Blades are attached to rock substratum by a basal rhizoidal holdfast. Thalli are monostromatic and monoecious. In sectional view, vegetative portions of blades are 
monostromatic, and their thickness range from 38.0 to $122.0 \mu \mathrm{m}$ (Figs. 7C-D). Sexual regions of the thalli are monoecious, 36.0-94.0 $\mu \mathrm{m}$ thick in transverse section and divided into separate male and female sectors by a vertical line. Spermatangia are light green while zygotosporangia are light reddish-brown (Figs. 7 E-H). Zygotosporangia are formed as continuous areas along most of the thallus, except the basal portion (vegetative and rhizoidal cells), whereas spermatangia develop along the margins of the blade. The division formula of spermatangia is $128(\mathrm{a} / 4, \mathrm{~b} / 4, \mathrm{c} / 8)$ whereas the division formula of zygotosporangia is $64(\mathrm{a} / 4, \mathrm{~b} / 4, \mathrm{c} / 4)$ (Figs. 7 E-H). Table 4 summarizes the detailed morphological features of 32 blades of Po. longissima identified through molecular assisted methods (i.e. PCR-RFLP).

Holotype: Voucher specimen $=$ SGO168348, housed in the herbarium of the National Museum of Natural History, Chile; sample code = CHC0010; gametophytic blade (reproductive) collected from boulders of the upper intertidal zone of Maitencillo beach (Chile: Valparaíso, 32³9’S, 71²6’W), coll. Zapata, Contreras-Porcia, 12 Aug 2014. (Fig. 7A). GenBank accession numbers: COI, MH123931 and rbcL, MH124021.

Distribution: Chile-from Atacama, Los Burros (285' S/71³1’W), to Los Ríos, Playa Rosada $\left(39^{\circ} 48^{\prime} \mathrm{S} / 73^{\circ} 24^{\prime} \mathrm{W}\right)$.

Habitat: Gametophytic thalli only registered in winter, growing on boulders surrounded by sandy bottom or even buried in sand (Fig. 2B).

Comments: Porphyra longissima Meynard, Ramírez, Contreras-Porcia, sp. nov. corresponds to the genetic species Porphyra sp. CHC, originally identified by Guillemin et al. (2016). 
Description: The gametangial blades are monostromatic and monoecious. Blades are 63.0-

$424 \quad 139.0 \mu \mathrm{m}$ thick in transverse section, oblong to lanceolate, sometimes cuneate or

425 acuminate, with wavy surface, $2.8-14.0 \mathrm{~cm}$ long and $1.1-7.0 \mathrm{~cm}$ wide, generally very

426 flexible and relatively resistant (Figs. 2D-E, Figs. 8A and 9A). Blade margins are entire to

427 undulate or lobate. Blades are attached to rock substratum by a basal or subcentral

428 rhizoidal holdfast. This species shows two different gametophytic morphotypes, occurring

429 in different intertidal microhabitats, and characterized principally by external morphology

430 (see Figs. 2D-E, Figs. 8A and 9A). The Green Morph (GM), consists of a single blade,

431 generally lanceolate and forest green to yellowish green in color (Figs. 2D and 8A). A

432 second morphotype, the Long Morph (LM), generally forestgreen to light-brown in color, is

433 characterized by a long central blade and one or two additional shorter blades arising from

434 a subcentral disc (Figs. 2E and 9A). LM blades are highly variable, being oblong to

435 lanceolate, cuneate or acuminate. In spite of their variable morphology, all fresh

436 gametophytic blades of $P y$. variabilis mostly display shades of green and present wavy

437 ruffled-margins (Figs. 2D-E). In sectional view, vegetative portions of blades are

438 monostromatic, and their thickness range from 63.0 to $137.0 \mu \mathrm{m}$ (Figs. 8C-D and 9C-D).

439 Sexual regions of the thalli are monoecious, 68.0-139.0 $\mu \mathrm{m}$ thick (Figs. 8E-H and 9E-H),

440 with contiguous groups of cells forming either spermatangia or zygotosporangia and

441 divided into separate male and female sectors by a vertical line. Reproductive cells are

442 formed as continuous areas along the margins of the blade. The division formula of

443 spermatangia is $128(\mathrm{a} / 4, \mathrm{~b} / 4, \mathrm{c} / 8)$ whereas the division formula of zygotosporangia is 16 
$444(\mathrm{a} / 2, \mathrm{~b} / 2, \mathrm{c} / 4)$ or $32(\mathrm{a} / 2, \mathrm{~b} / 4, \mathrm{c} / 4)$ (Figs. 8E-H and 9E-H). Table 4 summarizes the detailed

445 morphological features of 15 sequenced blades of $P y$. variabilis identified through

446 molecular assisted methods (i.e. sequencing and PCR-RFLP).

447 Holotype: Voucher specimen = SGO168333, housed in the herbarium of the National

448 Museum of Natural History, Chile; sample code = CHK0025; gametophytic blade

449 (reproductive) collected from a rocky platform of the upper intertidal zone of Maitencillo

450 beach (Chile: Valparaíso), 32 $39^{\prime} \mathrm{S}, 7^{\circ} 26^{\prime} \mathrm{W}$, coll. J. Zapata, L. Contreras-Porcia, 6

451 September 2013 (Fig. 9A). GenBank accession numbers: COI, MH123975 and rbcL,

452 MH124050.

453 Isotype: Voucher specimen = SGO168334, housed in the herbarium of the National

454 Museum of Natural History, Chile; sample code = CHK0028; gametophytic blade

455 (reproductive) collected from steep rock faces of the upper intertidal zone of Maitencillo

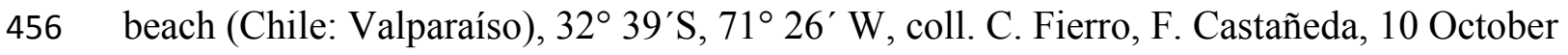

4572013 (Fig. 8A). GenBank accession numbers: COI, MH123978 and $r b c$ L, MH124051.

458 Distribution: Chile-from Antofagasta, Pan de Azúcar $\left(26^{\circ} 10^{\prime} \mathrm{S} / 70^{\circ} 38^{\prime} \mathrm{W}\right)$ to Coquimbo, 459 Horcón $\left(32^{\circ} 42^{\prime} \mathrm{S} / 71^{\circ} 29^{\prime} \mathrm{W}\right)$.

460 Habitat: Thalli of the GM morphotype grow on shady and humid steep rock faces (Fig.

461 2D). This morphotype is present mainly during the winter and spring seasons and is almost

462 absent in summer. Thalli of the LM morphotype grow on the sunnier and drier platforms of

463 the high intertidal (Fig. 2E). It is present mainly during the winter and spring seasons

464 (Zapata 2016). 
465 Etymology: variabilis-variable in shape. The name variabilis aims to describe the very 466 variable morphology of the gametophytic habit.

467 Comments: Pyropia variabilis Zapata, Meynard, Ramírez, Contreras-Porcia, sp. nov. 468 corresponds to the genetic species Pyropia sp. CHK, originally identified by Guillemin et 469 al. (2016).

\section{DISCUSSION}

Few molecular studies have characterized genetic and morphological local diversity

473 of bladed Bangiales and considered different types of habitats of the intertidal to describe

474 their distribution within this environment. We have confirmed the presence of five species

475 of bladed Bangiales in the rocky intertidal of Maitencillo beach, four of them being

476 dominant, during winter-spring 2013-2014. All correspond to species previously detected

477 by Guillemin et al. (2016) along the coasts of Chile, but our study report for the first time

478 the presence of Porphyra sp. CHF, Porphyra. sp. CHE and Porphyra. sp. CHC in

479 Maitencillo. Porphyra. sp. CHE was reported by Guillemin et al. (2016) in only one site

480 located at $29^{\circ} \mathrm{S}$ of latitude in Chile. It is clear that the species is probably more common

481 and broadly distributed than previously described, extending at least to Central Chile $\left(32^{\circ} \mathrm{S}\right.$

482 of latitude). Phylogenetic analyses of $r b c \mathrm{~L}$ and $C O I$ gene sequences (Figs. 1 and S2) were

483 not fully concordant, only the COI allowing to clearly separate Pyropia sp. CHJ, Pyropia

484 orbicularis and Pyropia sp. CHK as three highly supported monophyletic clades (Figs. 1

485 and $\mathrm{S} 3$ ). Incongruence between $r b c \mathrm{~L}$ and $C O I$ results could be the result of the lower base-

486 substitution mutation rate of the $r b c \mathrm{~L}$ gene for which incomplete lineage sorting and lack of 
487

488

489

490

491

492

493

494

495

496

497

498

499

500

501

502

503

504

505

506

507

508

509

510

monophyly has been observed in macroalgae species complex (Tellier et al. 2009,

Montecinos et al. 2012). COI sequences, in contrast, allowed to determine genetic species

in these recently diverged species complex. In red macroalgae, hybridization and

introgression have also been linked to the existence of incongruence between mitochondrial and chloroplast markers (Destombe et al. 2010). We cannot discard the possibility of past

and/or ongoing gene flow between the three Pyropia sp. CHJ, Pyropia orbicularis and

Pyropia sp. CHK, especially in central Chile where they co-occur (see Niwa et al. 2009 for an example of introgression in Bangiales, between Py. Yezoensis and Py. tenera).

In spite of significant differences between all pairs of species for four morphological characters, the huge variance in traits observed for Pyropia sp. CHK only allow to clearly separate the species Porphyra sp. CHC from the other three dominant bladed Bangiales of Maitencillo Beach using morphology. Indeed, Porphyra sp. CHC consistently shows extreme values of length and width of the thallus and thickness of the reproductive lamina (see Fig. 5). Porphyra sp. $\mathrm{CHC}$ is also the only species showing a specific habitat preference in the intertidal and was encountered only on boulders surrounded by pools of sandy bottom. This suggests that, unlike the other three dominant species present at the study site, Porphyra sp. CHC morphology and/or other associated characteristics (e.g. metabolites or physiological traits) could be central in explaining its local distribution. Interestingly, a recent study reported the presence of a morphologically very similar species of Porphyra with long thin blades, Po. mumfordii, on boulders surrounded by sand in central Chile (see Fig. 2 of Muñoz-Muga et al. 2018), supporting the possibility of morphs adapted to particular habitats.

Our study suggests that only one out of the four-dominant foliose Bangiales species show specific distributional ranges in the intertidal at Maitencillo since the distribution of 
511 Pyropia orbicularis, Porphyra sp. CHE and Pyropia sp. CHK overlap at the high intertidal

512 zone on the rocky platform and at the boulder zone surrounded by rocky pools.

513 Nevertheless, even if the three species were generally observed sympatrically, some

514 habitats seem mostly dominated by one species (e.g. Pyropia sp. CHK along the rocky

515 wall). As previously reported in distributional studies supported by molecular tools for

516 intertidal sites in New England, USA (West et al. 2005) and in the southern West Cape,

517 South Africa (Griffin et al. 1999), we expected that the abundance and occurrence of

518 specific intertidal zones by bladed Bangiales would differ. Indeed, in a highly

519 heterogeneous environment, in terms of landscape complexity, physical and chemical

520 variables and biotic interactions, differences in microhabitats could be expected among

521 related species (Billard et al. 2010, Couceiro et al. 2015, Muangmai et al. 2016, Montecinos

522 et al. 2017). Nonetheless, in our study, most specimens occurred in the high intertidal,

523 probably experiencing relatively homogeneous abiotic or biotic conditions during late

524 winter and early spring (i.e. study period). Accordingly, Scweikert et al. (2012) found no

525 distinct intertidal zonation patterns for bladed Porphyra sp. at Brighton Beach, southeast

526 New Zealand, with two dominant species showing a similar distributional pattern across

527 intertidal zones and seasons and seven other species being present only sporadically.

528 In the present study we have focused only on differences in zonation, but we did

529 not, however, test if Pyropia orbicularis, Porphyra sp. CHE and Pyropia sp. CHK

530 presented any differences in micro-ecological niches. Supporting this possibility, Scweikert

531 et al. (2012) hypothesized that the differing distributional patterns within and between

532 seasons observed in the generally overlapping Porphyra sp. in Brighton Beach could still

533 be explained by their differing degrees of physiological adaptation to abiotic factors.

534 Previous studies integrating finer sampling scale than in our study, or the one of Scweikert 
535

536

537

538

539

540

541

542

543

544

545

546

547

548

549

550

551

552

553

554

555

556

557

et al. (2012), and records of physical environmental factors in distinct micro-habitats, have revealed differences in micro-niche partitioning between related species of macroalgae. The study of Muangmai et al. (2016) describing the small-scale distribution of three sympatric cryptic species of the red alga Bostrychia intricata (Bory) Montagne (Ceramiales, Rhodophyta) along the shore of Moa Point, Wellington, New Zealand, selected sampling patches according to three a priori contrasting factors: tidal position, wave exposure, and sun exposure. Muangmai et al. (2016) demonstrated that the distribution of three cryptic species of Bostrychia in the intertidal was non-random, and highly influenced by tidal height and wave exposure. In the case of the brown algae Ectocarpus crouaniorum Thuret in Le Jolis and E. siliculosus (Dillwyn) Lyngbye, Coucerio et al. (2015) revealed that differences in micro-niches existed between species and phases (i.e. gametophytes and sporophytes). Along the European coast, the Fucus species complex (Fucales, Ochrophyta) was observed as the succession of different ecological species along a tidal gradient of contrasting habitats with a segregation between species in less than $50 \mathrm{~cm}$ on the vertical shore gradient (Billard et al. 2010). As in the marine gastropod Littorina saxatilis (Olivi), where ecotypes are segregated in different habitats along the shore (Butlin et al. 2008), divergence and speciation has been deemed to be driven by slight differences in ecological selective pressures as desiccation stress in Fucus (Billard et al. 2010). It is possible that our sampling was too coarse to detect microhabitat differences between Pyropia orbicularis, Porphyra sp. CHE and Pyropia sp. CHK in Maitencillo, and new field observation along a fine vertical shore gradient linked with the acquisition of data on physical environmental factors and biotic local interaction should now be performed. 
559 of the GM morphotype of Pyropia sp. CHK were dominant on rocky walls, with very low 560 presence of gametophytes of the LM morphotype of Pyropia sp. CHK or other bladed 561 Bangiales species therein (Zapata 2016, Betancourtt et al. 2018, this study). Interestingly, in 562 the study of Coucerio et al. (2015), two ecotypes were observed among the E. siliculosus 563 sporophytes sampled in North West France with one ecotype encountered as epiphyte on 564 several different algal hosts and the other attached to abiotic substrates. The authors 565 proposed that these two ecotypes probably arose due to phenotypic plasticity in the case of 566 E. siliculosus. Our molecular data sets include only sequences of the $C O I$ and $r b c \mathrm{~L}$ genes

567 and these were not sufficiently variable to detect genetic difference between our two 568 Pyropia sp. CHK ecotypes. However, these two molecular markers are characterized by 569 low mutational rates in comparison to microsatellites (Jarne and Lagoda 1996), and we 570 cannot discard the hypothesis of possible genetic adaptation of the GM morphotype in

571 Pyropia sp. CHK to the conditions encountered on the step walls of Maitencillo. To 572 determine if the two ecotypes within Pyropia sp. CHK are due to phenotypic plasticity or 573 represent traits related to intraspecific genetic differentiation and adaptation, samples

574 should be genotyped using more variables markers (i.e. microsatellites or SNP's) that allow 575 testing for signatures of selection (e.g. Schlotterer 2000, Haasl et al. 2014). We also 576 propose that transplant experiments and/or common garden experiments should be 577 considered to complement the population genetic analyses and to test for adaptation (e.g. de 578 Villemereuil et al. 2016). CONCLUSIONS As pointed out by Sutherland et al. 2011 (following Matsuyama-Serisawa et al. 582 2004) the very simple and at the same time highly variable morphology of foliose 
583 Bangiales make taxonomic identification using key morphological traits an unresolved 584 problem in this group. On the other hand, phylogenetic reconstructions using molecular 585 markers have revealed cryptic diversity at the genus and species level in Porphyra and 586 Pyropia (e.g. Guillemin et al. 2016 in Chile), and allowed the accurate reassignment of 587 these organisms (e.g. Nelson and Broom 2010 in New Zealand). In our study, in spite of 588 substantial sample sizes and significant differences between all pairs of species for various 589 morphological characters, the overlap observed in morphological trait values between 590 Porphyra and Pyropia species suggests that morphology is not sufficient to delineate 591 genetic species in this group. In spite of this, some clear morphological differences were 592 observed among the four species of foliose Bangiales analyzed, such as the differential 593 thickness of the blade. This trait was associated with a differential degree of palatability 594 (Niwa et al. 2008) and would have a potential utility in the selection of strains (each 595 belonging to one or more species) for the food industry. Scweikert et al. (2012) proposed 596 that the very similar morphology between some foliose Bangiales implies that they 597 developed the most suited thallus shape for their gametophytes in their habitat. In this case, 598 an optimal (and common) structure in phenotypic morphology in this group of algae would 599 have been shaped by the particular genetic, developmental and environmental constraints 600 operating on these algal taxa (Rosen 1967). The rapid and accurate identification of local 601 genetic diversity in foliose Bangiales recently achieved using molecular techniques 602 (Scweikert et al. 2012, Nelson et al. 2013, Dumilag et al. 2016, Guillemin et al. 2016, 603 Reddy et al. 2018, Yang et al. 2018) will allow researchers to refine the knowledge about 604 the intrinsic and environmental determinants of their distribution across tidal gradients of 605 contrasting habitats and climates. 
608 This work was supported by FONDECYT 1120117, 1170881, and DI-501-14/R \& DI609 1245-16/R (Universidad Andrés Bello) awarded to LC-P. We would like to thank two 610 anonymous reviewers for their insightful and constructive comments.

611 
613

614

615

616

617

618

619

620

621

622

623

624

625

626

627

628

629

630

631

632

633

634

635

636

637

638

639

640

641

642

643

644

645

Abdi, H. \& Williams, L. J. 2010. Honestly significant difference (HSD) test. In Salkind, N.J., Dougherty, D.M. \& Frey, B. [Ed.] Encyclopedia of Research Design, Sage, Thousand Oaks, CA, USA (2010), pp. 583-585.

Aguilar-Rosas, R. \& Aguilar-Rosas, L. E. 2003. El género Porphyra (Bangiaceae, Rhodophyta) en la costa Pacífico de México. I. Porphyra suborbiculata Kjellman. Hidrobiológica, 13:51-56.

Anderson, M.J. 2001. A new method for non-parametric multivariate analysis of variance. Austral Ecol., 26:32-46.

Bandelt, H-J., Forster, P. \& Röhl, A. 1999. Median-Joining Networks for Inferring Intraspecific Phylogenies. Mol. Biol. Evol. 16:37-48.

Betancourtt, C., Zapata, J., Latorre, N., Anguita, C., Castañeda, F., Meynard, A., Fierro, C., Espinoza, C., Guajardo, E., Núñez, A., Salas, N., González, C., Ramírez, M.L., Bulboa-Contador, C. \& Contreras-Porcia, L. 2018. Spatio-temporal variation in the composition of the macroalgae assemblage of the intertidal rocky zone from Maitencillo, Valparaíso, central coast of Chile. Rev. Biol. Mar. Oceanogr. 53(1):105117.

Billard, E., Serrao, E., Pearson, G; Destombe, C. \& Valero, M. 2010. Fucus vesiculosus and spiralis species complex: a nested model of local adaptation at the shore level. Mar. Ecol. Prog. Ser. 405:163-174.

Blouin, N. A., Brodie, J. A., Grossman, A. C., Xu, P. \& Brawley, S. H. 2011. Porphyra: a marine crop shaped by stress. Trends Plant Sci. 16:29-37.

Box, G.E. P. \& Cox, D. R. 1964. An analysis of transformations (with discussion). J. R. Stat. Soc. Series B. Stat. Methodol. 26:211-252.

Brodie, J., Bartsch, I., Neefus, C., Orfanidis, S., Bray, T. \& Mathieson, A. C. 2007. New insights into the cryptic diversity of the North Atlantic-Mediterranean Porphyra leucosticta complex: P. olivii sp. nov. and P. rosengurttii (Bangiales, Rhodophyta). Eur. J. Phycol. 42:3-28.

Broom, J. E., Nelson, W. A., Yarish, C., Jones, W. A., Aguilar-Rosas, R. \& Aguilar-Rosas, L. E. 2002. A reassessment of the taxonomic status of Porphyra suborbiculata, Porphyra carolinensis and Porphyra lilliputiana (Bangiales, Rhodophyta) based on molecular and morphological data. Eur. J. Phycol. 37:227-35.

Butlin, R. K., Galindo, J. \& Grahame, J. W. 2008. Sympatric, parapatric or allopatric: the most important way to classify speciation? Transt. R. Soc. B. 363: 2997-3007.Collén 
646

J \& Davison IR. 1999a. Reactive oxygen production and damage in intertidal Fucus spp.(Phaeophyceae). J. Phycol. 35: 54-61.

Collén, J., \& Davison, I. R. 1999b. Stress tolerance and reactive oxygen metabolism in the intertidal red seaweeds Mastocarpus stellatus and Chondrus crispus. Plant, Cell \& Environment. 22(9): 1143-1151.

Couceiro, L., Le Gac, M., Hunsperger, H.M., Mauger, S., Destombes, C., Cock, J.M., Ahmed, S., Coelho, S.M., Valero, M. \& Peters, A.F. 2015. Evolution and maintenance of haploid-diploid life cycles in natural populations: The case of the marine brown alga Ectocarpus. Evolution 69-7:1808-1822.

Destombe, C., Valero, M., \& Guillemin, M-L. 2010. Diversity and natural hybridization in two related red algae species: Gracilaria gracilis and Gracilaria dura using multi DNA markers: resurrection of the species G. dura previously described in the Northern Atlantic 200 years ago. J. Phycol. 46:720-727.

de Villemereuil, Gaggiotti, O.E., Mouterde, M. \& Till-Bottraud, I. 2016. Common garden experiments in the genomic era: new perspectives and opportunities. Heredity 116:249-254.

Dillehay, T.D. 2008. Monte Verde: Seaweed, Food, Medicine, and the Peopling of South America. Science 320:784-6.

Dumilag, R.V., Aguinaldo, Z-Z.A., Mintu, C.B., Quinto, M.P., Ame, E.C., Andres, R.C., Monotilla, W.D. \& Yap, S.L. 2016. Morphological and molecular confirmation of the occurrence of Pyropia tanegashimensis (Bangiales, Rhodophyta) from Palaui Is., Sta. Ana, Cagayan, Philippines. Phytotaxa 255:83-90.

Faugeron, S., Valero, M., Destombe, C., Martínez, E. A. \& Correa J. A. 2001. Hierarchical spatial structure and discriminant analysis of genetic diversity in the red alga Mazzaella laminarioides (Gigartinales, Rohodophyta). J. Phycol. 37:705-16.

Flores-Molina, M.R., Thomas, D., Lovazzano, C., Núñez, A., Zapata, J., Kumar, M., Correa, J.A. \& Contreras-Porcia, L. 2014. Desiccation stress in intertidal seaweeds: effects on morphology, antioxidant responses and photosynthetic performance. Aquat. Bot. 113:90-99.

Fredericq, S., Anderson, R. J. \& Lopez-Bautista, J. M. 2003. Circumscription of some Phyllophoraceae (Gigartinales, Rhodophyta) from the Cape region, South Africa, based on molecular evidence. Proc. Int. Seaweed Symp. 17:263-73.

Guillemin, M. L., Contreras-Porcia, L., Ramírez, M. E., Macaya, E. C., Bulboa-Contador, C., Woods, H., Wyatt, C. \& Brodie, J. 2016. The bladed Bangiales (Rhodophyta) of 
the South Eastern Pacific: Molecular species delimitation reveals extensive diversity. Mol. Phylogenet. Evol. 94:814-26.

Griffin, N. J., Bolton, J. J. \& Anderson, R. J. 1999. Porphyra aeodis sp. nov. (Bangiales, Rhodophyta), an epiphyte of Aeodes orbitosa from South Africa. Eur. J. Phycol. 34:505-12.

Haasl, R.J., Jonson, R.C. \& Payseur, B.A. 2014. The effects of microsatellite selection on linked sequences diversity. Genome Biol. Evol. 6(7):1843-1861.

Hall, T.A. 1999. BioEdit: a user-friendly biological sequence alignment editor and analysis program for Windows 95/98/NT. Nucl. Acids. Symp. Ser. 41:95-8.

Hammer, Ø., Harper, D.A.T., and P. D. Ryan, 2001. PAST: Paleontological Statistics Software Package for Education and Data Analysis. Palaeontologia Electronica 4(1): 9pp.

Hilton, Z., Wellenreuther, M., \& Clements, K. D. 2008. Physiology underpins habitat partitioning in a sympatric sister species pair of intertidal fishes. Funct. Ecol. 22: $1108-1117$.

Hoffmann, A., Santelices, B., 1997. Flora marina de Chile central (Marine Flora of Central Chile). Universidad Católica de Chile, Santiago, Chile (in Spanish).

Hommersand, M. H., Fredericq, S. \& Freshwater, D. W. 1994. Phylogenetic systematics and biogeography of the Gigartinaceae (Gigartinales, Rodophyta) based on the sequence analysis of rbcL. Bot. Mar. 37:193-203.

Hurd, C.L., Harrison, P.J., Bischof, K. \& Lobban, C.H. 2014. Seaweed Ecology and Physiology. 2nd ed. Cambridge University Press, Cambridge, 551 pp.

Jarne, P. \& Lagoda, P.J.L. 1996. Microsatellites, from molecules to populations and back. TREE. 11 (10):424-429.

Koh, Y.H. \& Kim, M.S. 2018. DNA barcoding reveals cryptic diversity of economic red algae, Pyropia (Bangiales, Rhodophyta): description of novel species from Korea. $J$. Appl. Phycol. https://doi.org/10.1007/s10811-018-1529-8.

Krueger-Hadfield, S.A., Collén, J., Daguin-Thiébaut, C. \& Valero, M. 2011. Genetic population structure and mating system in Chondrus crispus (Rhodophyta). J Phycol. 47:440-450.

Krueger-Hadfield, S.A., Roze, D., Mauger, S. \& Valero, M. 2013 Intergametophytic selfing and microgeographic genetic structure shape populations of the intertidal red seaweed Chondrus crispus. Mol. Ecol. 22:3242-60. 
713

714

715

716

717

718

719

720

721

722

723

724

725

726

727

728

729

730

731

732

733

734

735

736

737

738

739

740

741

742

743

744

745

746

Lindstrom, S. C., Hughey, J. R. \& Aguilar-Rosas, L. E. 2015. Four new species of Pyropia (Bangiales, Rhodophyta) from the west coast of North America: the Pyropia lanceolata species complex updated. PhytoKeys 52:1-22.

Martin Henry H. Stevens, adapted to vegan by Jari Oksanen: Community Ecology Package. 2009. R package vegan version 1.16-32. http://cran.r-project.org/, http://vegan.rforge.r-project.org/

Matsuyama-Serisawa, K., Couceiro, L., Yamazaki, S., Kitade, Y., Serisawa, Y., Kuwano, K. \& Saga, N. 2004. Tracing of systematic characters of Bangiales (Rhodophyta) based on molecular phylogeny inferred from sequences of nuclear small subunit rRNA genes. Suisanzoshoku 52:185-198.

Montecinos, A., Broitman, B.R., Faugeron, S., Haye, P.A., Tellier, F. \& Guillemin, M.L. 2012. Species replacement along a linear coastal habitat: phylogeography and speciation in the red alga Mazzaella laminaroides along the south east pacific. BMC. Evol. Biol. 12(1):97.

Montecinos, A.E., Couceiro, L., Peters, A.F., Desrut, A., Valero, M., \& Guillemin, M.L. 2017. Species delimitation and phylogeographic analyses in the Ectocarpus subgroup siliculosi (Ectocarpales, Phaeophyceae). J. Phycol. 53:17-31.

Muangmai, N., von Ammon, U. \& Zuccarello, G.C. 2016. Cryptic species in sympatry: nonrandom small-scale distribution patterns in Bostrychia intricata (Ceramiales, Rhodophyta). Phycologia 55:424-30.

Muñoz-Muga, P., Romo, H., Calderón, C., Evrard, O. \& Díaz, H. 2018. Amplificación del gen $r b c \mathrm{~L}$ revela primer registro de Porphyra mumfordii (Bangiales, Rhodophyta) en la Bahía de Valparaíso, Chile central. Rev. Biol. Mar. Oceanogr. 53(1):131-140.

Neefus, C. D., Mathieson, A. C., Bray, T. L. \& Yarish, C. 2008. The distribution, morphology, and ecology of three introduced asiatic species of Porphyra (Bangiales, Rhodophyta) in the Northwestern Atlantic. J. Phycol. 44:1399-414.

Nelson, W. A. \& Broom, J.E.S. 2010. Porphyra columbina (Bangiales, Rhodophyta): originally described from the New Zealand subantarctic islands. Austral. Syst.Bot. 23:16-26.

Nelson, W. A. 2013. Pyropia plicata sp. nov. (Bangiales, Rhodophyta): naming a common intertidal alga from New Zealand. PhytoKeys 21:17-28.

Nguyen, L.T., Schmidt, H.A., von Haeseler, A. \& Minh, B.Q. 2015. IQ-TREE: a fast and effective stochastic algorithm for estimating maximum-likelihood phylogenies. Mol. Biol. Evol. 32: 268-274. 
Niwa, K., Kobiyama, A. \& Aruga, Y. 2005. Confirmation of cultivated Porphyra tenera (Bangiales, Rhodophyta) by polymerase chain reaction restriction fragment length polymorphism analyses of the plastid and nuclear DNA. Phycol. Res. 53: 296-302.

Niwa, K. \& Aruga, Y. 2006. Identification of currently cultivated Poprhyra species by PCR-RFLP analysis. Fisheries Science. 72:143-48.

Niwa, K., Furuita, H. \& Yamamoto, T. 2008. Changes of growth characteristics and free amino acid content of cultivated Porhyra yezoensis Ueda (Bangiales, Rhodophyta) blades with the progression of the number of harvest in a nori farm. Fisheries Science. 72:143-48.

Niwa, K., Iida, S., Kato, A., Kawai, H., Kikuchi, N., Kobiyama, A. \& Aruga, Y. 2009. Genetic diversity and introgression in two cultivated species (Porphyra yezoensis and Porphyra tenera) and closely related wild species of Porphyra (Bangiales, Rhodophyta). J. Phycol. 45:493-502.

Niwa, K., Kobiyama, A. \& Sakamoto, T. 2010a. Interspecific hybridization in the haploid blade-forming marine crop Porphyra (Bangiales, Rhodophyta): occurrence of allodiploidy in surviving F1 gametophytic blades. J. Phycol. 46:693-702.

Niwa, K. \& Sakamoto, T. 2010b. Allopolyploidy in natural and cultivated populations of Porphyra (Bangiales, Rhodophyta). J. Phycol. 46:1097-1105.

Niwa, K. \& Kobiyama, A. 2014. Speciation in the marine crop Pyropia yezoensis (Bangiales, Rhodophyta). J. Phycol. 50:897-900.

Niwa, K., Kikuchi, N., Hwang, M.S., Choi, H.G., Aruga, Y., 2014. Cryptic species in the Pyropia yezoensis complex (Bangiales, Rhodophyta): sympatric occurrence of two cryptic species even on same rocks. Phycol. Res. 62: 36-43.

Pons, J., Barraclough, T. G., Gomez-Zurita, J., Cardoso, A., Duran, D. P., Hazell, S., Kamoun, S., Sumlin, W. D. \& Vogler, A. P. 2006. Sequence-Based species delimitation for the DNA taxonomy of undescribed insects. Syst. Biol. 55:595-609.

R Development Core Team. 2017. R: A language and environment for statistical computing. R Foundation for Statistical Computing, Vienna, Austria. ISBN 3900051-07-0, URL http://www.R-project.org.

Ramírez, M.E., Contreras-Porcia, L., Guillemin, M.L., Brodie, J., Valdivia, C., FloresMolina, M.R., Núñez, A, Bulboa Contador, C. \& Lovazzano, C. 2014. Pyropia orbicularis sp. nov. (Rhodophyta, Bangiaceae) based on a population previously known as Porphyra columbina from the central coast of Chile. Phytotaxa 158:133153. 
781

782

783

784

785

786

787

788

789

790

791

792

793

794

795

796

797

798

799

800

801

802

803

804

805

806

807

808

809

810

811

812

813

814

Reddy, M.M., A, De Clerck, O., Leliaert, F., Anderson, R.J. \& Bolton, J.J. 2018. A rosette by any other name: species diversity in the Bangiales (Rhodophyta) along the South African coast. Eur. J. Phycol. 53:267-82.

Rosen, R. 1967. Optimality Principles in Biology. In: The Vascular System, Butterworths, London, Chapter 3, 41-60.

Sánchez, N., Vergés, A., Peteiro, C., Sutherland, J.E. \& Brodie, J. 2014. Diversity of bladed Bangiales (Rhodophyta) in western Mediterranean: recognition of the genus Themis and descriptions of T. iberica sp. nov., and Pyropia parva sp. nov. J. Phycol. 50:90829.

Salzburger, W., Ewing, G.B. \& Von Haeseler, A. 2011. The performance of phylogenetic algorithms in estimating haplotype genealogies with migration. Mol. Ecol. 20:19521963.

Saunders, G.W. 1993. Gel purification of red algal genomic DNA: an inexpensive and rapid method for the isolation of polymerase-chain reaction-friendly DNA. J. Phycol. 29:251-54.

Saunders, G.W. 2005. Applying DNA barcoding to red macroalgae: a preliminary appraisal holds promise for future applications. Phil. Trans. R. Soc. B. 360:1879-1888.

Schlotterer, C. 2002. A microsatellite-based multilocus screen for the identification of local selective sweeps. Genetics 160:753-763.

Schweikert, K., Sutherland, J.E., Burritt, D.J. \& Hurd, C.L. 2012. Analysis of spatial and temporal diversity and distribution of Porphyra (Rhodophyta) in southeastern New Zealand supported by the use of molecular tools. J. Phycol. 48:530-38.

Sutherland, J.E., Lindstrom, S., Nelson, W., Brodie, J., Lynch, M., Hwang, M.S., Choi, H. G., Miyata, M., Kikuchi, N., Oliveira, M., Farr, T., Neefus, C., Mortensen, A., Milstein, D. \& Müller, K. 2011. A new look at an ancient order: generic revision of the Bangiales. J. Phycol. 47:1131-1151.

Tamura, K., Stecher, G., Peterson, D., Filipski, A. \& Kumar, S. 2013. Molecular evolutionary genetics analysis version 6.0. Mol. Biol. Evol. 30:2725-2729.

Teasdale, B., West, A., Taylor, H.E. \& Klein, A.S. 2002. A simple Restriction Fragment Length Polymorphism (RFLP) Assay to discriminate common Porphyra (Bangiophyceae, Rhodophyta) taxa from the Northwest Atlantic. J. Appl. Phycol. 38:293-298.

Tellier, F., Meynard, A.P., Correa, J.A., Faugeron, S. \& Valero, M. 2009. Phylogeographic analysis of the $30^{\circ} \mathrm{S}$ south-east Pacific biogeographic transition zone establish the 
837

occurrence of a sharp genetic discontinuity in the kelp Lessonia nigrescens: Vicariance or parapatry? Mol. Phyl. Evol. 53(3): 679-693.

Trifinopoulos, J., Nguyen, L.T., von Haeseler, A. \& Minh, B.Q. 2016. W-IQ-TREE: a fastonline phylogenetic tool for maximum likelihood analysis. Nucleic Acids Res. 44(W1): W232-5.

Vanelslander, B., Creach, V., Vanormelingen, P., Ernst, A., Chepurnov, V. A., Sahan, E., ... \& Sabbe, K. 2009. Ecological differentiation between sympatric pseudocryptic species in the estuarine benthic diatom Navicula phyllepta (Bacillariophyceae). $J$. Phycol. 45: 1278-1289.

West, A.L., Mathieson, A.C., Klein, A.S., Neefus, C.D. \& Bray, T.L. 2005. Molecular ecological studies of New England species of Porphyra (Rhodophyta, Bangiales). Nova Hedwigia 80:1-24.

Yang, L.E., Zhou, W., Hu, C.M., Deng, Y.Y., Xu, G.P., Zhang, T., Russell, S., Zhu, J.Y., Lu, Q.Q. \& Brodie, J. 2018. A molecular phylogeny of the bladed Bangiales (Rhodophyta) in China provides insights into biodiversity and biogeography of the genus Pyropia. Mol. Phyl. Evol. 120:94-102.

Zapata, J. 2016. Diferenciación ecológica entre ecotipos de dos especies hermanas de Pyropia (Bangiales, Rhodophyta) mediado por estrés ambiental. Tesis de grado en Magister en Biología Marina, Facultad de Ecología y Recursos Naturales, Universidad Andrés Bello.

Zuccarello, J. 2011. What are you eating? It may be nori, but it is probably not Porphyra anymore. J. Phycol. 47:967-8.

.

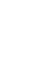


846 Table 1. Distribution of the five taxa of foliose Bangiales sampled in the site of Maitencillo 847 along different intertidal habitats: Pyropia sp. CHK, Pyropia orbicularis, Porphyra sp. 848 CHE, Porphyra sp. CHC and Porphyra sp. CHF. Species delimitation was based on 849 molecular criteria using sequences of COI (66 sequences) and $r b c \mathrm{~L}$ (46 sequences).

\begin{tabular}{ccccccc}
\hline \hline & \multicolumn{6}{c}{ INTERTIDAL HABITATS } \\
\cline { 2 - 7 } Species & Rocky Wall & High & Medium & Low & $\begin{array}{c}\text { Boulders } \\
\text { (rocky pools) }\end{array}$ & $\begin{array}{c}\text { Boulders } \\
\text { (sandy pools) }\end{array}$ \\
\hline Pyropia sp. CHK & 15 & 13 & 0 & 0 & 4 & 0 \\
Pyropia orbicularis & 1 & 3 & 0 & 0 & 0 & 0 \\
Porphyra sp. CHE & 1 & 9 & 0 & 0 & 6 & 0 \\
Porphyra sp. CHC & 0 & 0 & 0 & 0 & 0 & 12 \\
Porphyra sp. CHF & 0 & 0 & 0 & 0 & 2 & 0 \\
\hline
\end{tabular}


852 Table 2. AFA I cut sites (base position) among the variable bases of the aligned $r b c \mathrm{~L}$ 853 sequences of Pyropia sp. CHK, Pyropia orbicularis, Porphyra sp. CHE and Porphyra sp.

854 CHC. A total of 873 sites were analyzed using the program Webcutter 2.0. We show base 855 positions going from the forward to the reverse primers and indicate as reference for base 856 position the $r b c \mathrm{~L}$ sequence AB818919.1 of Pyropia yezoensis retrieved from Genbank. It is 857 worth mentioning that amplified fragments used for PCR-RFLP were larger (1230 bp) than 858 our obtained sequences (873 bp). See Materials and Methods for more details.

\begin{tabular}{lcccc}
\hline Base Position & 582 & 765 & 996 & 1134 \\
\hline Pyropia sp. CHK & T & C & T & T \\
Pyropia orbicularis & T & C & T & A \\
Porphyra sp. CHE & C & T & A & A \\
Porphyra sp. CHC & T & T & A & A \\
\hline
\end{tabular}


Table 3. Nested Permanova carried out on the eight microscopic and two macroscopic morphological characters measured for four dominant sympatric Pyropia and Porphyra species. Null hypothesis: no morphological differences between species.

\begin{tabular}{ccccccc}
\hline \hline Source of Variation & $\mathbf{d f}$ & Sums of Sqs & Mean Sqs & F. Model & $\mathbf{R}^{2}$ & Pr(>F) \\
\hline Species & 3 & 1.10743 & 0.36914 & 1583.01 & 0.44084 & $0.001^{* * *}$ \\
Species/Plant & 88 & 1.23304 & 0.01401 & 60.09 & 0.49084 & $0.001^{* * *}$ \\
Residuals & 736 & 0.17163 & 0.00023 & & 0.06832 & \\
Total & 827 & 2.51210 & & & 1.00000 & \\
\hline \hline
\end{tabular}


1 Table 4. Habits and morphological features of Pyropia variabilis sp. nov. (CHK), Porphyra

2 luchensis sp. nov. (CHE), Porphyra longissima sp. nov. (CHC), and Pyropia orbicularis

3 from Maitencillo beach, Valparaíso, Chile.

4

\begin{tabular}{|c|c|c|c|c|}
\hline Feature & Pyropia orbicularis & Pyropia variabilis & Porphyra luchensis & Porphyra longissima \\
\hline $\begin{array}{l}\text { Size blade } \\
(\mathrm{cm}, \text { length } \times \text { width })\end{array}$ & $2.8-5.5 \times 2.4-5.3$ & $2.8-14.0 \times 1.1-7.0$ & $5.4-22.0 \times 0.5-9.0$ & $16.0-50.0 \times 0.3-3.5$ \\
\hline Shape & $\begin{array}{l}\text { Orbicular (Several } \\
\text { laminae interwined) }\end{array}$ & $\begin{array}{l}\text { Oblong to lanceolate (one or } \\
\text { several laminae) }\end{array}$ & $\begin{array}{l}\text { Reniform to spear-shaped } \\
\text { asymmetrical (One lamina) }\end{array}$ & $\begin{array}{l}\text { Linear to lanceolate, } \\
\text { very long (one lamina) }\end{array}$ \\
\hline Color & Green-brown & Forestgreen to light-brown & Redish-brown to green & Rosy pinky to brown \\
\hline Habitat & $\begin{array}{l}\text { Upper-mid intertidal } \\
\text { zone }\end{array}$ & $\begin{array}{l}\text { Upper-mid intertidal zone } \\
\text { and steep rock faces }\end{array}$ & $\begin{array}{l}\text { Boulders surrounded by stony } \\
\text { ground and rocky platforms }\end{array}$ & $\begin{array}{c}\text { Boulders surrounded } \\
\text { by sand }\end{array}$ \\
\hline Seasonality & $\begin{array}{l}\text { Year-round: } \\
\text { More abundant in } \\
\text { Spring and Summer }\end{array}$ & $\begin{array}{l}\text { Year-round: } \\
\text { More abundant in Winter } \\
\text { and Spring }\end{array}$ & $\begin{array}{c}\text { Year-round: } \\
\text { More abundant in Winter and } \\
\text { Spring }\end{array}$ & Present only in Winter \\
\hline Sexuality & Monoecious & Monoecious & Monoecious & Monoecious \\
\hline $\begin{array}{l}\text { Vegetative thickness } \\
(\mu \mathrm{m})\end{array}$ & $68-128$ & $63-137$ & $68-156$ & $38-122$ \\
\hline $\begin{array}{l}\text { Reproductive } \\
\text { thickness }(\mu \mathrm{m})\end{array}$ & $72-130$ & $68-139$ & $39-136$ & $36-94$ \\
\hline $\begin{array}{l}\text { Vegetative cells } \\
(\mu \mathrm{m}, \text { length } \times \text { width })\end{array}$ & $16-30 \times 10-22$ & $12-35 \times 8-27$ & $17-43 \times 12-29$ & $9-42 \times 6-30$ \\
\hline $\begin{array}{l}\text { Rhizoidal cells } \\
(\mu \mathrm{m}, \text { length } \times \text { width })\end{array}$ & $17-46 \times 15-41$ & $16-55 \times 14-48$ & $24-59 \times 21-48$ & $13-49 \times 4-40$ \\
\hline Spermatangium & $\mathrm{a} 4 / \mathrm{b} 4 / \mathrm{c} 4$ & $\mathrm{a} 4 / \mathrm{b} 4 / \mathrm{c} 8$ & $\mathrm{a} 4 / \mathrm{b} 4 / \mathrm{c} 8$ & $\mathrm{a} 4 / \mathrm{b} 4 / \mathrm{c} 8$ \\
\hline Zygotosporangium & $\mathrm{a} 2 / \mathrm{b} 2 / \mathrm{c} 4$ & $\mathrm{a} 2 / \mathrm{b} 2 / \mathrm{c} 4$ or $\mathrm{a} 2 / \mathrm{b} 4 / \mathrm{c} 4$ & $\mathrm{a} 2 / \mathrm{b} 4 / \mathrm{c} 8$ or $\mathrm{a} 4 / \mathrm{b} 4 / \mathrm{c} 8$ & $\mathrm{a} 4 / \mathrm{b} 4 / \mathrm{c} 4$ \\
\hline
\end{tabular}


FIGURE LEGENDS

9

10 Figure 1. Maximum likelihood (ML) trees of Pyropia and Porphyra using Boreophylum

11 birdiae and Bangia fuscopurpurea as outgroups, respectively, and based on DNA

12 sequences of the cytochrome oxidase I (COI) gene. a) Details of the Pyropia COI ML tree

13 (outgroup not shown). b) Details of the Porphyra COI ML tree (outgroup not shown). For

14 each node, ML bootstrap values are indicated. Only high support values $(>80)$ are shown.

15 For species for which two or more sequences were considered in the analyses branches

16 have been collapsed for easier reading and are represented as triangles. Black triangles

17 indicate species present at the study site, Maitencillo Beach.

18

19 Figure 2. Habit of the four dominant genetic species of foliose Bangiales observed at

20 Maitencillo beach. Scale bar $=10 \mathrm{~cm}$. For taxonomical characteristics see Table 4 and

21 Results section. A) Porphyra sp. CHE, B) Porphyra sp. CHC, C) Pyropia orbicularis, D)

22 Pyropia sp. CHK LM (Long Morph), E) Pyropia sp. CHK GM (Green Morph).

23

24 Figure 3. PCR-RFLP profiles resulting from the digestion of the $1230 \mathrm{bp} r b c \mathrm{~L}$

25 amplification fragment by the enzyme AFA I. Restriction pattern observed for the four

26 dominant genetic species found at the intertidal in Maitencillo Beach are shown. Legend for

27 each lane corresponds to: Marker, molecular weight marker (bp: base pairs); Po. $\mathrm{CHC}=$

28 Porphyra sp. CHC; Po. CHE = Porphyra sp. CHE, Py. CHK = Pyropia sp. CHK; and Py.

29 orb = Pyropia orbicularis. PD: primer dimer products. 
Figure 4. PCA plot carried out for two microscopic and two macroscopic traits (i.e. normalized data after Box-Cox transformation) measured in specimens of the fourdominant foliose Bangiales observed at Maitencillo beach. Points correspond to scores for each specimen (gametophyte) in the coordinates of the principal components $\mathrm{PC} 1$ and $\mathrm{PC} 2$, and ellipses indicate the $95 \%$ confidence intervals of the scores for each species. Green vectors are projections of the original variables into the new axes of the principal components. The greatest contribution to $\mathrm{PC} 1$ is from the thallus length and thallus width and allows separating Porphyra sp. CHC (with the longest and thinnest blades) from the other three species. Red - Porphyra sp. CHC; pink - Porphyra sp. CHE; green - Pyropia sp. CHK and brown - Pyropia orbicularis.

Figure 5. Boxplot of the sizes of two out of eight microscopic traits (all in $\log \mu \mathrm{m}$ ) and two out of two macroscopic traits (in $\log \mathrm{cm}$ ) measured in the four-dominant foliose Bangiales species observed at Maitencillo beach. Different letters indicate statistically significant differences between species in Tukey multiple comparisons test. Po. $\mathrm{CHC}=$ Porphyra sp. $\mathrm{CHC} ;$ Po. $\mathrm{CHE}=$ Porphyra sp. $\mathrm{CHE} ;$ Py. $\mathrm{CHK}=$ Pyropia sp. $\mathrm{CHK} ;$ and Py. orb. $=$ Pyropia orbicularis.

Figure 6. Images of macro and micromorphology of Porphyra luchensis sp. nov., SGO168338, holotype, Museo Nacional de Historia Natural, Santiago, Chile (Table S1). A) Habit of the foliose gametophyte sampled from the intertidal zone in Maitencillo beach, Valparaíso, Chile (scale bar $=10 \mathrm{~cm}$ ). B) Surface view of basal, rhizoidal cells. C) Surface 2 view of vegetative region of the thallus. D) Cross-section of vegetative region of thallus. E) 
53 Surface view of zygotosporangia. F) Cross-section of zygotosporangial region of thallus.

54 G) Surface view of spermatangia (smaller and colourless). H) Cross-section of 55 spermatangial region of thallus. Scale bar B-H $=20 \mu \mathrm{m}$.

56

57

58 Figure 7. Images of macro and micromorphology of Porphyra longissima sp. nov., 59 SGO168348, holotype, Museo Nacional de Historia Natural, Santiago, Chile (Table S1). A)

60 Habit of the foliose gametophyte sampled from the intertidal zone in Maitencillo beach,

61 Valparaíso, Chile (scale bar $=10 \mathrm{~cm}$ ). B) Surface view of basal, rhizoidal cells. C) Surface

62 view of vegetative region of the thallus. D) Cross-section of vegetative region of thallus. E)

63 Surface view of zygotosporangia. F) Cross-section of zygotosporangial region of thallus.

64 G) Surface view of spermatangia (smaller and colourless). H) Cross-section of 65 spermatangial region of thallus. Scale bar B-H $=20 \mu \mathrm{m}$.

66

67

68 Figure 8. Images of macro and micromorphology of Pyropia variabilis sp. nov. (CHK)

69 Green Morph (GM), SGO168334, isotype, Museo Nacional de Historia Natural, Santiago,

70 Chile (Table S1). A) Habit of the foliose gametophyte sampled from the intertidal zone in

71 Maitencillo beach, Valparaíso, Chile (scale bar $=10 \mathrm{~cm}$ ). B) Surface view of basal,

72 rhizoidal cells. C) Surface view of vegetative region of the thallus. D) Cross-section of

73 vegetative region of thallus. E) Surface view of zygotosporangia. F) Cross-section of

74 zygotosporangial region of thallus. G) Surface view of spermatangia (smaller and 75 colourless). H) Cross-section of spermatangial region of thallus. Scale bar B-H $=20 \mu \mathrm{m}$. 
77 Figure 9. Images of macro and micromorphology of Pyropia variabilis sp. nov. (CHK) 78 Long Morph (LM), SGO168333, holotype, Museo Nacional de Historia Natural, Santiago, 79 Chile (Table S1). A) Habit of the foliose gametophyte sampled from the intertidal zone in 80 Maitencillo beach, Valparaíso, Chile (scale bar $=10 \mathrm{~cm}$ ). B) Surface view of basal, 81 rhizoidal cells. C) Surface view of vegetative region of the thallus. D) Cross-section of 82 vegetative region of thallus. E) Surface view of zygotosporangia. F) Cross-section of 83 zygotosporangial region of thallus. G) Surface view of spermatangia (smaller and 84 colourless). H) Cross-section of spermatangial region of thallus. Scale bar B-H $=20 \mu \mathrm{m}$. 

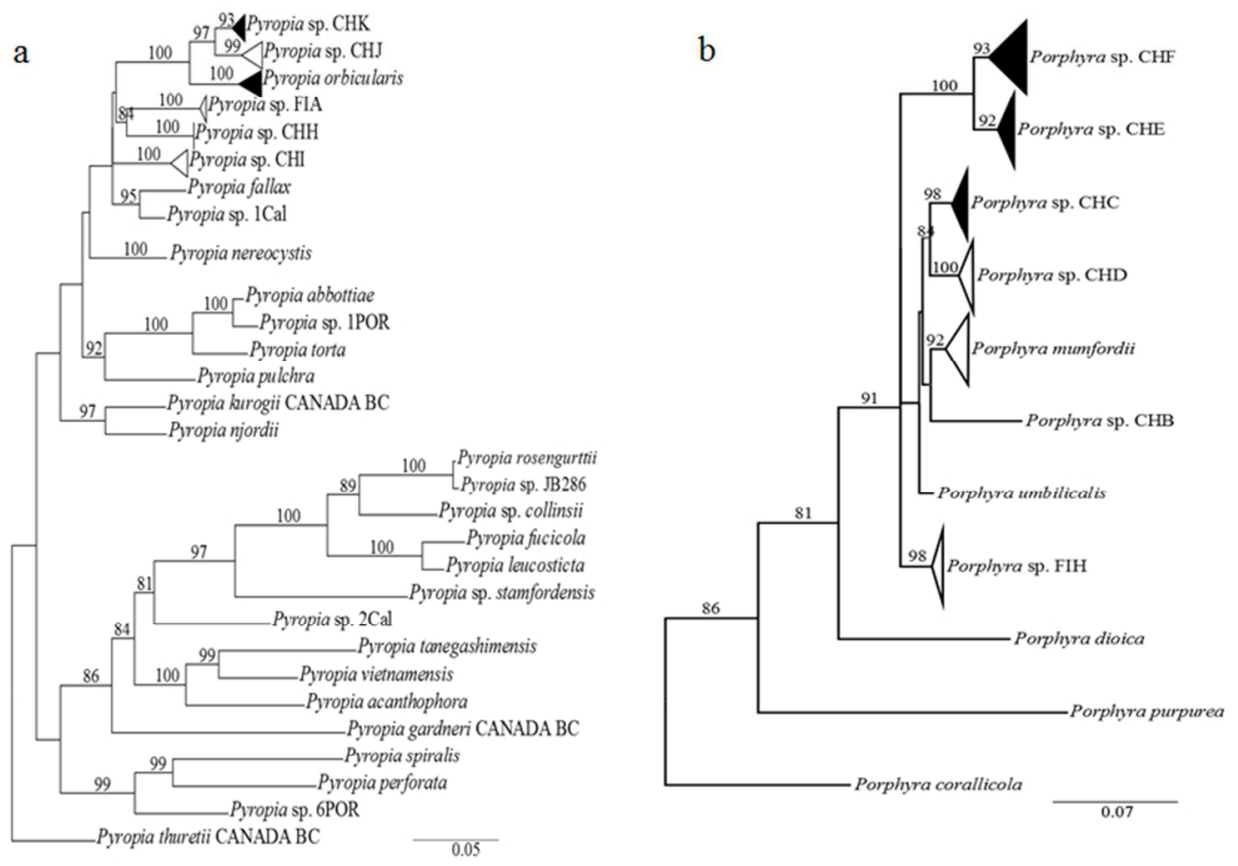

Figure 1. Maximum likelihood (ML) trees of Pyropia and Porphyra using Boreophylum birdiae and Bangia fuscopurpurea as outgroups, respectively, and based on DNA sequences of the cytochrome oxidase I (COI) gene. a) Details of the Pyropia COI ML tree (outgroup not shown). b) Details of the Porphyra COI ML tree (outgroup not shown). For each node, ML bootstrap values are indicated. Only high support values (>80) are shown. For species for which two or more sequences were considered in the analyses branches have been collapsed for easier reading and are represented as triangles. Black triangles indicate species present at the study site, Maitencillo Beach. 


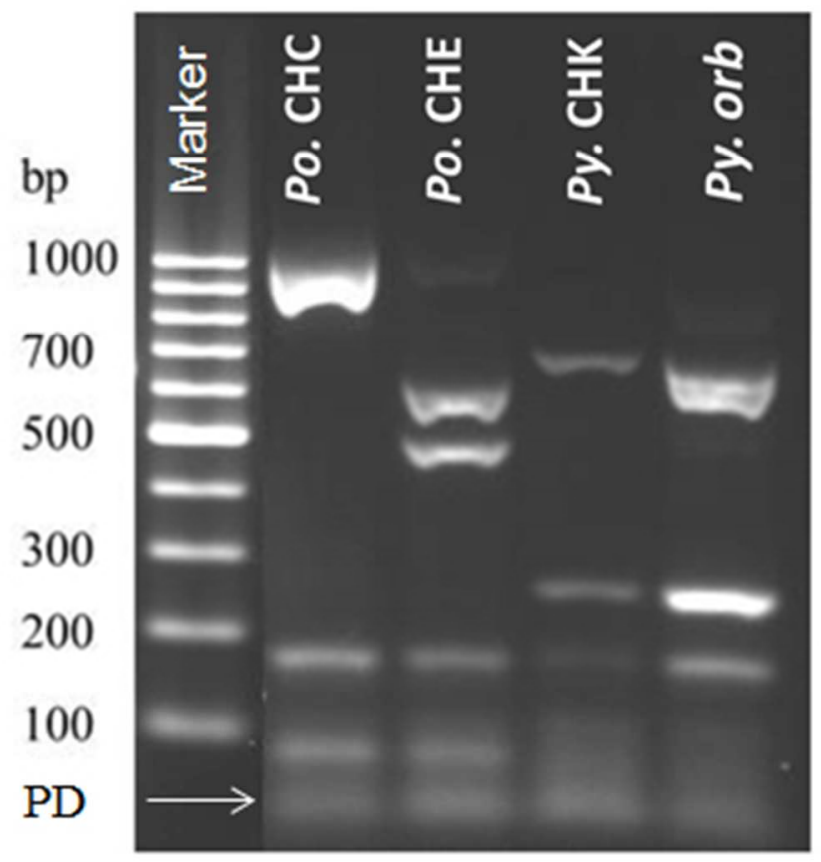

Figure 3. PCR-RFLP profiles resulting from the digestion of the $1230 \mathrm{bp} \mathrm{rbcL}$ amplification fragment by the enzyme AFA I. Restriction pattern observed for the four dominant genetic species found at the intertidal in Maitencillo Beach are shown. Legend for each lane corresponds to: Marker, molecular weight marker (bp: base pairs); Po. $\mathrm{CHC}=$ Porphyra sp. $\mathrm{CHC}$; Po. $\mathrm{CHE}=$ Porphyra sp. $\mathrm{CHE}, \mathrm{Py} . \mathrm{CHK}=$ Pyropia sp. $\mathrm{CHK}$; and Py. orb $=$ Pyropia orbicularis. PD: primer dimer products.

$84 \times 90 \mathrm{~mm}(96 \times 96 \mathrm{DPI})$ 


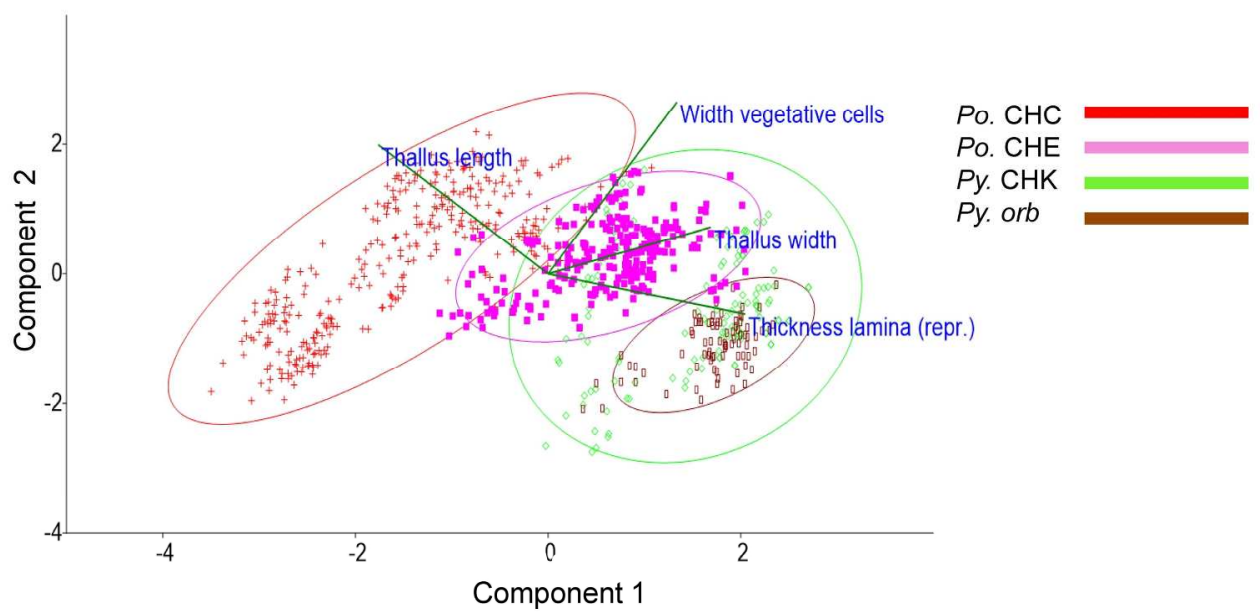

PCA plot carried out for two microscopic and two macroscopic traits (i.e. normalized data after Box-Cox transformation) measured in specimens of the four-dominant foliose Bangiales observed at Maitencillo beach. Points correspond to scores for each specimen (gametophyte) in the coordinates of the principal components PC1 and PC2, and ellipses indicate the 95\% confidence intervals of the scores for each species. Green vectors are projections of the original variables into the new axes of the principal components. The greatest contribution to PC1 is from the thallus length and thallus width and allows separating Porphyra sp. $\mathrm{CHC}$ (with the longest and thinnest blades) from the other three species. Red - Porphyra sp. CHC; pink Porphyra sp. CHE; green - Pyropia sp. CHK and brown - Pyropia orbicularis.

$108 \times 53 \mathrm{~mm}(600 \times 600 \mathrm{DPI})$ 
Thallus length

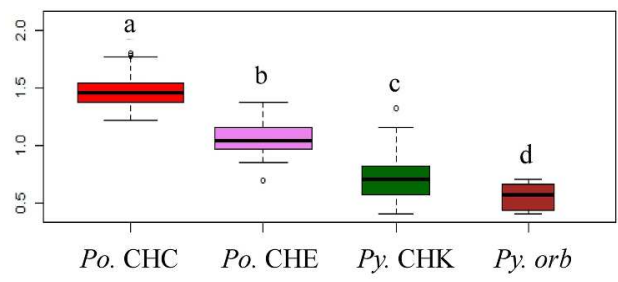

Thickness reproductive lamina

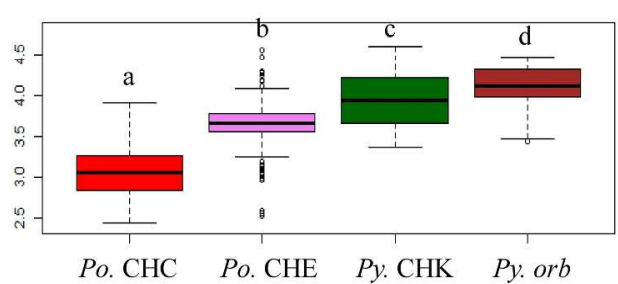

Thallus width

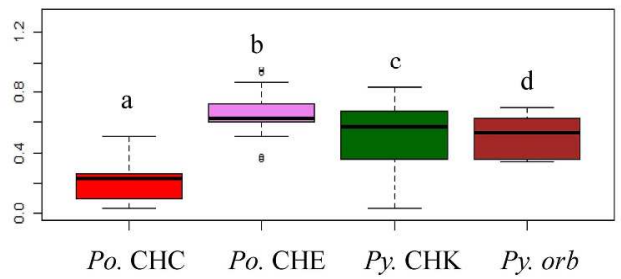

Width vegetative cell

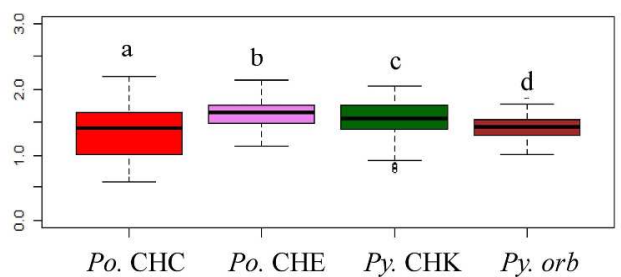

Boxplot of the sizes of two out of eight microscopic traits (all in Log $\mu \mathrm{m}$ ) and two out of two macroscopic traits (in Log $\mathrm{cm}$ ) measured in the four-dominant foliose Bangiales species observed at Maitencillo beach. Different letters indicate statistically significant differences between species in Tukey multiple comparisons test. Po. $\mathrm{CHC}=$ Porphyra sp. CHC; Po. CHE = Porphyra sp. CHE; Py. CHK= Pyropia sp. CHK; and Py. orb. = Pyropia orbicularis. 
Figure S1. Study site (map is given on the right) and google earth image of the Maitencillo beach including the locations of the intertidal habitats sampled during this study (given on the left). The three central lines, perpendicular to the beach, represent three sampling transects on the rocky platform. Colors correspond to the three intertidal zones sampled (for more details on zone delimitation see Materials and Methods): lower intertidal (green), middle intertidal (purple) and upper intertidal (red). The circle indicates the steep wall, the rhombus indicates the boulder zone surrounded by rocky pools, and the triangle indicates the boulder zone surrounded by pools of sandy bottoms (all are in colored in red since they were located in the upper intertidal zone). Scale bar, in white, $100 \mathrm{~m}$.

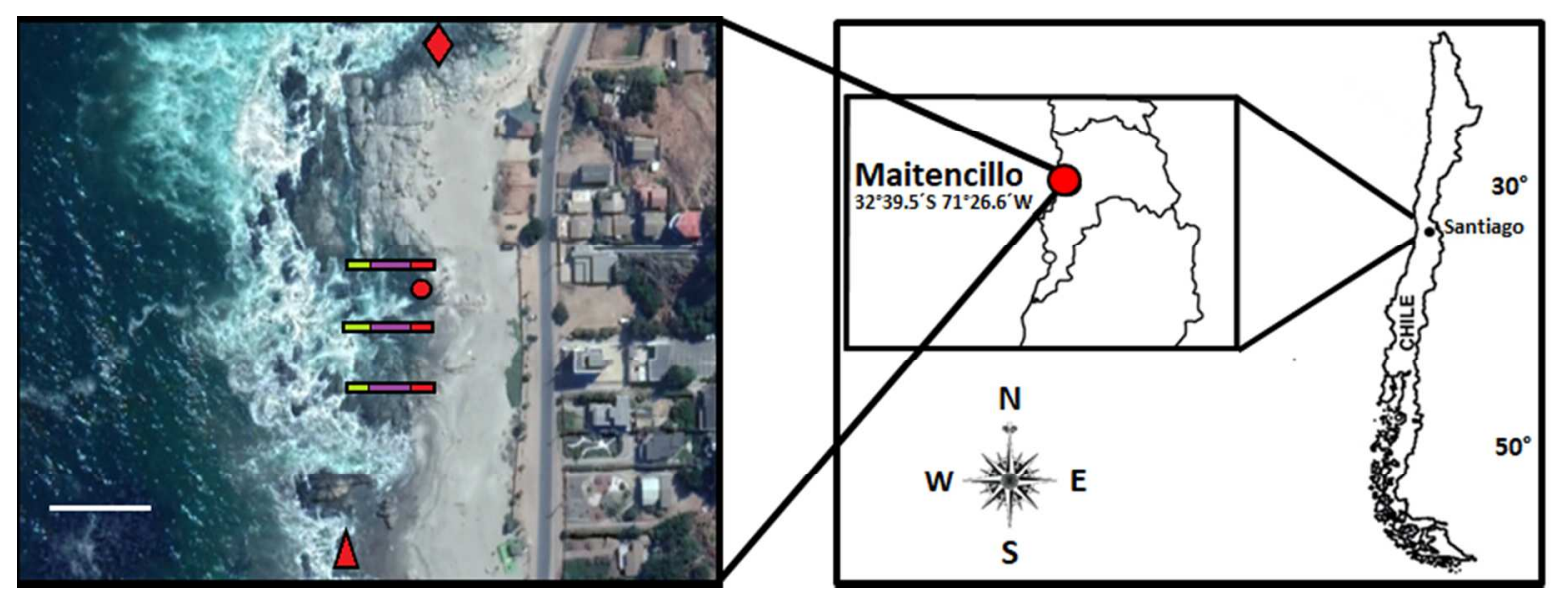


Figure S2. Details of the Maximum Likelihood (ML) rooted tree for $r b c \mathrm{~L}$ sequences $(873 \mathrm{bp}$ ) of Bangiales. The complete tree is not shown but is similar to the one presented in Fig. 1 in Guillemin et al. (2016), save for some difference in branch support. a) Details of the Porphyra clade of the Bangiales $r b c \mathrm{~L}$ ML rooted tree. b) Details of the Pyropia clade of the Bangiales $r b c \mathrm{~L}$ ML rooted tree. For each node, ML bootstrap values are indicated. Only high support values $(>80)$ are shown. For species for which two or more sequences were considered in the analyses branches have been collapsed for easier reading and are represented as triangles. Grey triangles indicate species present at the study site, Maitencillo Beach.

\section{a}

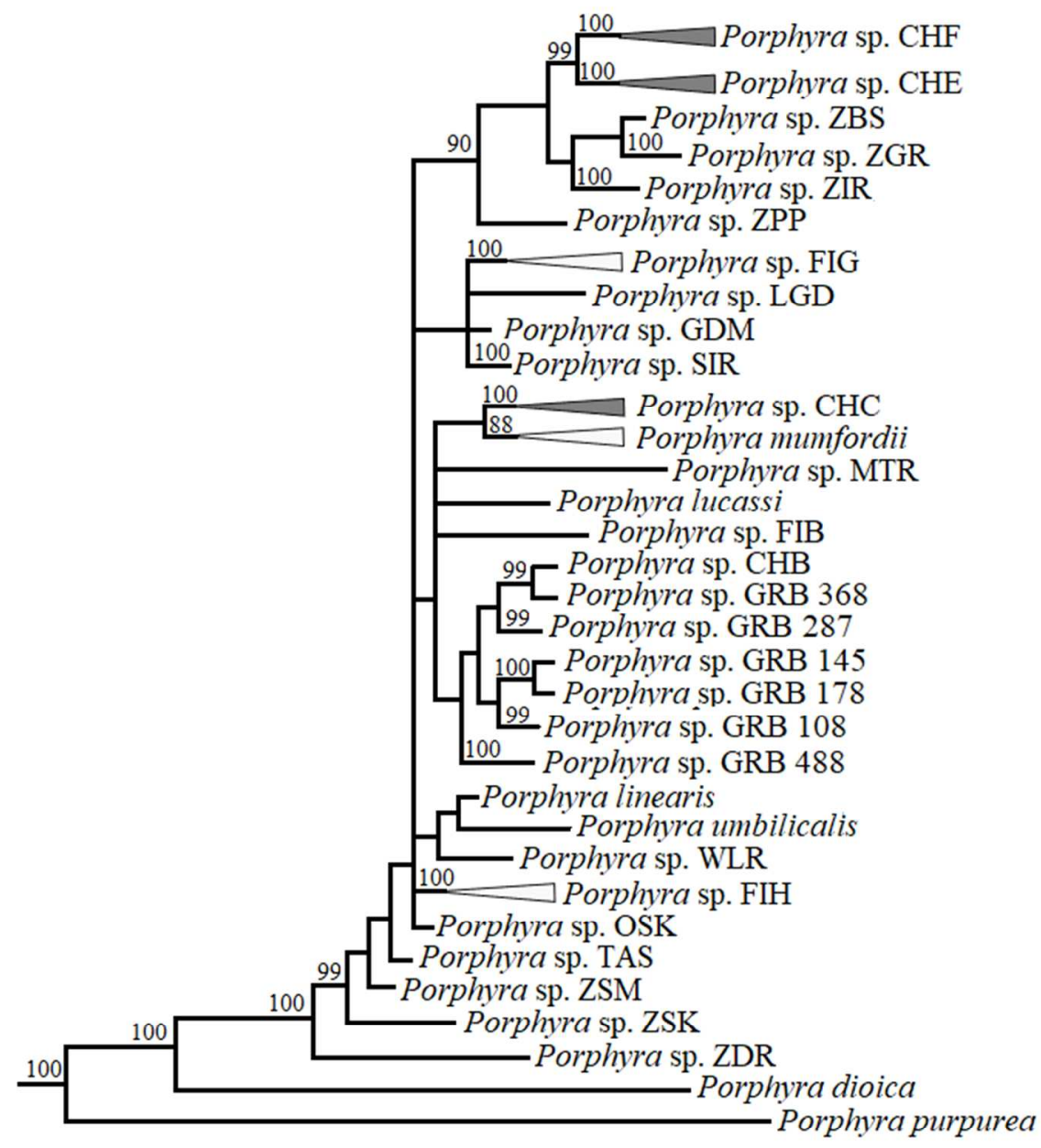


b

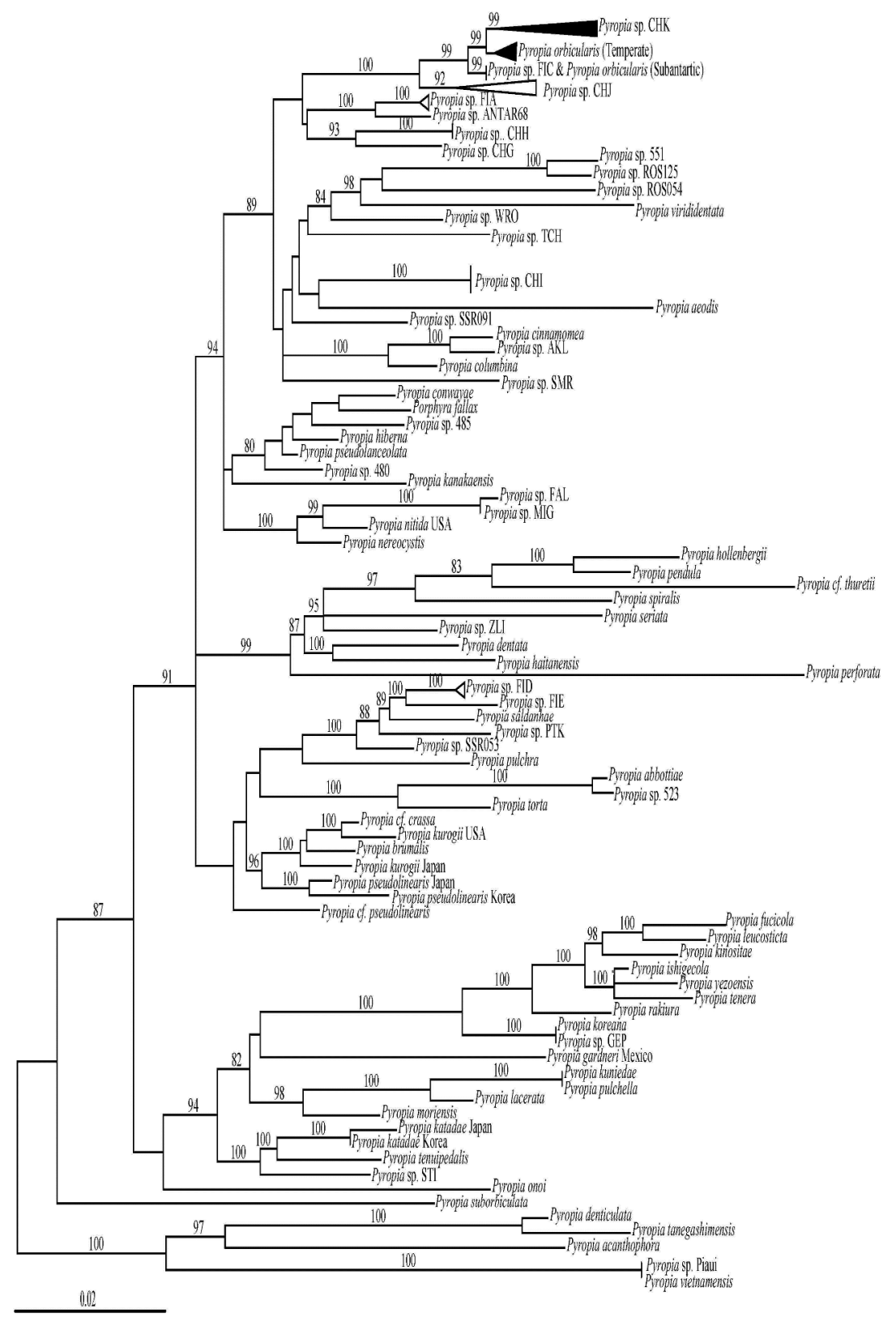


Figure S3: Haplotype network reconstructed using the COI data set for the Pyropia orbicularis, Pyropia sp. CHJ and Pyropia sp. CHK species complex. Each circle represents one haplotype and its size is proportional to the frequency in which the haplotype was encountered. White represents sequences from previous studies already deposited in GenBank and black the sequences acquired during this study. Non-interrupted blue lines represent one mutation step. When more than one mutational step separated two haplotypes, the number of segments (i.e. blue line disrupted by blue dots) indicated the number of steps.

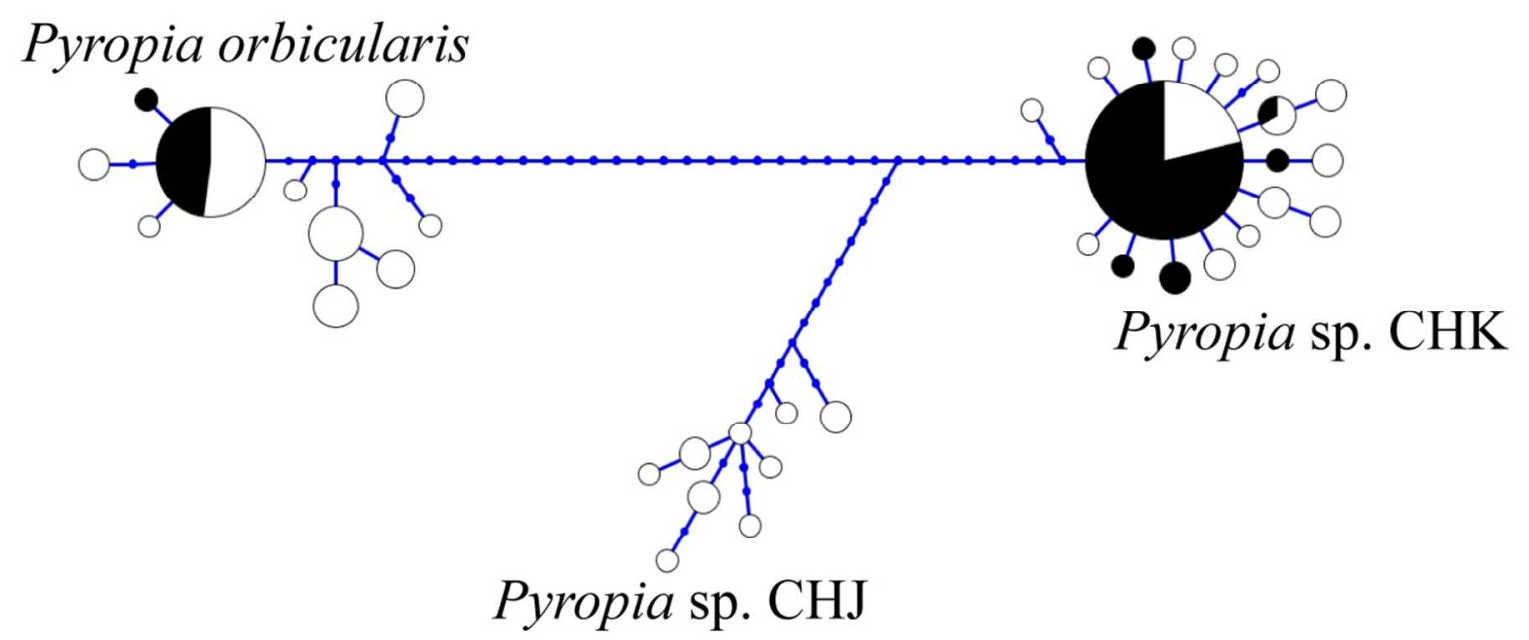


Figure S4. Images of macro and micromorphology of Pyropia orbicularis Ramírez, Contreras-Porcia \& Guillemin. A) Habit of the foliose gametophyte sampled from the intertidal zone in Maitencillo beach, Valparaíso, Chile (scale bar=10 cm). B) Surface view of basal, rhizoidal cells. C) Surface view of vegetative region of the thallus. D) Crosssection of vegetative region of thallus. E) Surface view of zygotosporangia. F) Crosssection of zygotosporangial region of thallus. G) Surface view of spermatangia (smaller and colourless). H) Cross-section of spermatangial region of thallus. Scale bar B-H $=20 \mu \mathrm{m}$.

\section{Pyropia orbicularis}

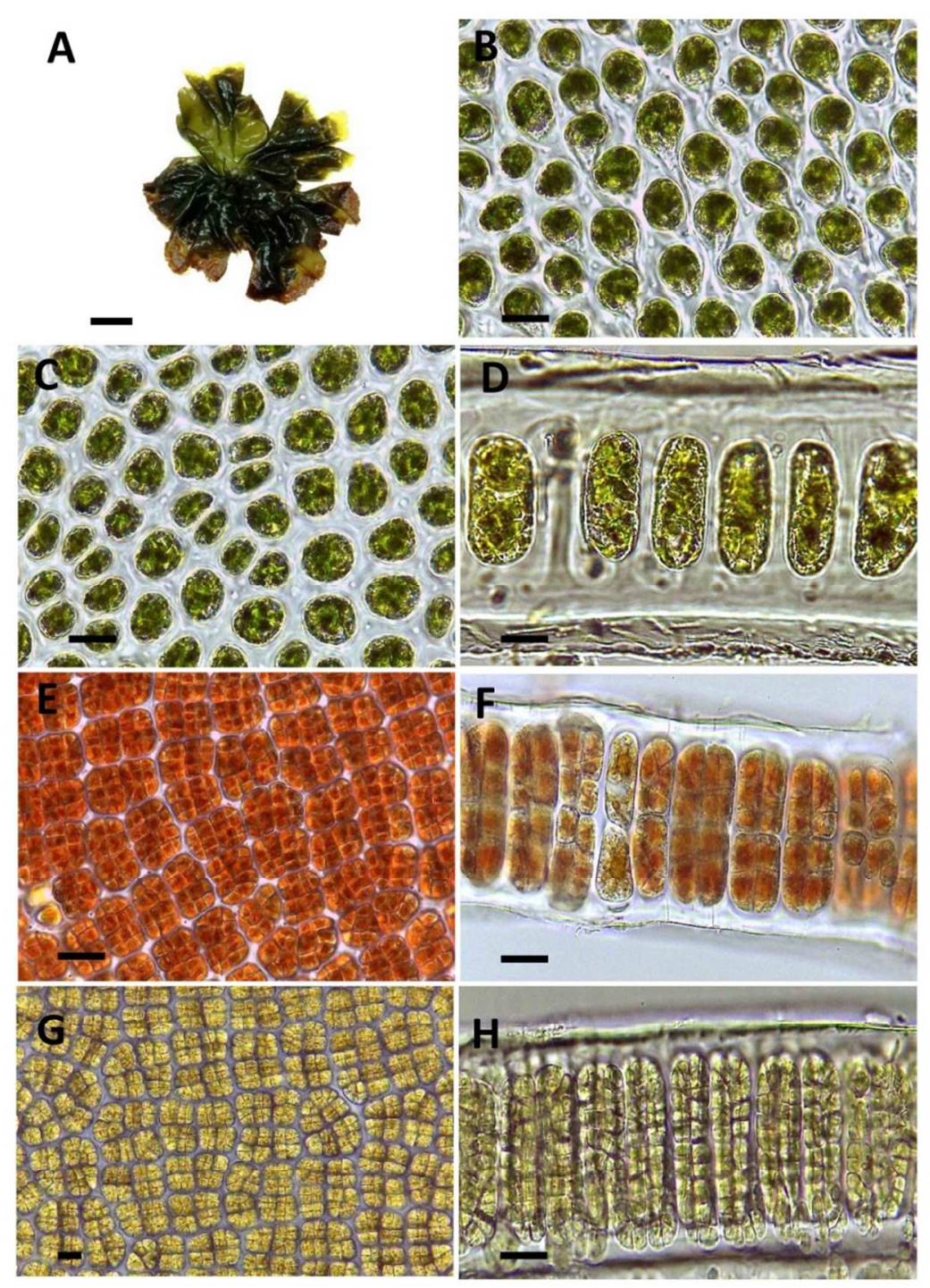


Table S1. Specimen collection information, voucher numbers and GENBANK accession numbers of Pyropia sp. CHK, Porphyra sp. CHC, Porphyra sp. CHE and Pyropia orbicularis from Maitencillo beach, Valparaíso, Chile, sequenced during this work.

\begin{tabular}{|c|c|c|c|}
\hline \multirow[t]{2}{*}{ Collection data } & \multirow{2}{*}{$\begin{array}{l}\text { Sample code/ } \\
\text { voucher number }\end{array}$} & \multicolumn{2}{|c|}{ GENBANK accession number } \\
\hline & & $\mathrm{COI}$ & $r b c \mathrm{~L}$ \\
\hline $\begin{array}{l}\text { 12/08/2014. Collector: J. Zapata, } \\
\text { L.Contreras-Porcia }\end{array}$ & CHC0001/ SGO168341 & MH123922 & MH124012 \\
\hline $\begin{array}{l}\text { 12/08/2014. Collector: J. Zapata, } \\
\text { L.Contreras-Porcia }\end{array}$ & CHC0002/ SGO168342 & MH123923 & MH124013 \\
\hline $\begin{array}{l}\text { 12/08/2014. Collector: J. Zapata, } \\
\text { L.Contreras-Porcia }\end{array}$ & CHC0003/SGO168343 & MH123924 & MH124014 \\
\hline $\begin{array}{l}\text { 12/08/2014. Collector: J. Zapata, } \\
\text { L.Contreras-Porcia }\end{array}$ & CHC0004/ SGO168344 & MH123925 & MH124015 \\
\hline $\begin{array}{l}\text { 12/08/2014. Collector: J. Zapata, } \\
\text { L.Contreras-Porcia }\end{array}$ & CHC0005/ SGO168345 & MH123926 & MH124016 \\
\hline $\begin{array}{l}\text { 12/08/2014. Collector: J. Zapata, } \\
\text { L.Contreras-Porcia }\end{array}$ & $\mathrm{CHC0006}$ & MH123927 & MH124017 \\
\hline $\begin{array}{l}\text { 12/08/2014. Collector: J. Zapata, } \\
\text { L.Contreras-Porcia }\end{array}$ & CHC0007/ SGO168346 & MH123928 & MH124018 \\
\hline $\begin{array}{l}\text { 12/08/2014. Collector: J. Zapata, } \\
\text { L.Contreras-Porcia }\end{array}$ & CHC0008/ SGO168347 & MH123929 & MH124019 \\
\hline $\begin{array}{l}\text { 12/08/2014. Collector: J. Zapata, } \\
\text { L.Contreras-Porcia }\end{array}$ & $\mathrm{CHC} 0009$ & MH123930 & MH124020 \\
\hline $\begin{array}{c}\text { 12/08/2014. Collector: J. Zapata, } \\
\text { L.Contreras-Porcia }\end{array}$ & CHC0010/ SGO168348 & MH123931 & MH124021 \\
\hline $\begin{array}{l}\text { 12/08/2014. Collector: J. Zapata, } \\
\text { L.Contreras-Porcia }\end{array}$ & CHC0011/SGO168349 & MH123932 & MH124022 \\
\hline
\end{tabular}




\begin{tabular}{cccc}
\hline $\begin{array}{c}\text { 12/08/2014. Collector: J. Zapata, } \\
\text { L.Contreras-Porcia }\end{array}$ & CHC0012/ SGO168350 & MH123933 & MH124023 \\
\hline $\begin{array}{c}\text { 08/09/2014. Collector: J. Zapata, } \\
\text { L.Contreras-Porcia }\end{array}$ & CHE0001 & MH123934 & MH124024 \\
\hline $\begin{array}{c}\text { 08/09/2014. Collector: J. Zapata, } \\
\text { L.Contreras-Porcia }\end{array}$ & CHE0002 & MH123935 & MH124025 \\
\hline $\begin{array}{c}\text { 08/09/2014. Collector: J. Zapata, } \\
\text { L.Contreras-Porcia }\end{array}$ & CHE0004 & MH123936 & MH124026 \\
\hline $\begin{array}{c}\text { 08/09/2014. Collector: J. Zapata, } \\
\text { L.Contreras-Porcia }\end{array}$ & CHE0005 & MH123937 & MH124027 \\
\hline $\begin{array}{c}\text { 08/09/2014. Collector: J. Zapata, } \\
\text { L.Contreras-Porcia }\end{array}$ & CHE0007 & MH123938 & \\
\hline 08/09/2014. Collector: J. Zapata, & & & \\
L.Contreras-Porcia & CHE0008 & MH123939 & MH124028 \\
\hline 08/09/2014. Collector: J. Zapata, & & & \\
L.Contreras-Porcia & CHE0012 & MH123940 & MH124029 \\
\hline 08/09/2014. Collector: J. Zapata, & & & \\
L.Contreras-Porcia & CHE0019 & MH123941 & - \\
\hline 08/09/2014. Collector: J. Zapata, \\
L.Contreras-Porcia
\end{tabular}




\begin{tabular}{|c|c|c|c|}
\hline F.Castañeda & & & \\
\hline $\begin{array}{c}\text { 08/09/2014. Collector: C.Fierro, } \\
\text { F.Castañeda }\end{array}$ & CHE0030/SGO168340 & MH123947 & - \\
\hline $\begin{array}{c}\text { 08/09/2014. Collector: J. Zapata, } \\
\text { L.Contreras-Porcia }\end{array}$ & CHE0036 & MH123948 & - \\
\hline $\begin{array}{c}\text { 08/09/2014. Collector: J. Zapata, } \\
\text { L.Contreras-Porcia }\end{array}$ & CHE0035 & MH123949 & MH124033 \\
\hline $\begin{array}{c}\text { 08/09/2014. Collector: J. Zapata, } \\
\text { L.Contreras-Porcia }\end{array}$ & CHF0003 & MH123950 & MH124034 \\
\hline $\begin{array}{c}\text { 08/09/2014. Collector: J. Zapata, } \\
\text { L.Contreras-Porcia }\end{array}$ & CHF0010 & MH123951 & MH124035 \\
\hline $\begin{array}{c}\text { 08/09/2014Collector: J. Zapata, } \\
\text { L.Contreras-Porcia }\end{array}$ & CHK006p & MH123953 & MH124037 \\
\hline $\begin{array}{c}\text { 08/09/2014Collector: J. Zapata, } \\
\text { L.Contreras-Porcia }\end{array}$ & CHK009p & MH123954 & MH124038 \\
\hline $\begin{array}{c}\text { 08/09/2014Collector: J. Zapata, } \\
\text { L.Contreras-Porcia }\end{array}$ & CHK0011p & MH123952 & MH124040 \\
\hline $\begin{array}{c}\text { 28/07/2014. Collector: J. Zapata, } \\
\text { L.Contreras-Porcia }\end{array}$ & CHK0001/SGO168324 & MH123955 & - \\
\hline $\begin{array}{c}\text { 28/07/2014. Collector: J. Zapata, } \\
\text { L.Contreras-Porcia }\end{array}$ & CHK0002/SGO168325 & MH123956 & MH124041 \\
\hline $\begin{array}{l}\text { 28/07/2014. Collector: J. Zapata, } \\
\text { L.Contreras-Porcia }\end{array}$ & CHK0003/SGO168326 & MH123957 & - \\
\hline $\begin{array}{l}\text { 28/07/2014. Collector: J. Zapata, } \\
\text { L.Contreras-Porcia }\end{array}$ & CHK0005 & MH123958 & - \\
\hline $\begin{array}{c}\text { 28/07/2014. Collector: J. Zapata, } \\
\text { L.Contreras-Porcia }\end{array}$ & CHK005b & MH123959 & - \\
\hline
\end{tabular}




\begin{tabular}{|c|c|c|c|}
\hline $\begin{array}{l}\text { 28/07/2014. Collector: J. Zapata, } \\
\text { L.Contreras-Porcia }\end{array}$ & CHK0006 & MH123960 & - \\
\hline $\begin{array}{c}\text { 28/07/2014. Collector: J. Zapata, } \\
\text { L.Contreras-Porcia }\end{array}$ & CHK006b & MH123961 & MH124043 \\
\hline $\begin{array}{l}\text { 28/07/2014. Collector: J. Zapata, } \\
\text { L.Contreras-Porcia }\end{array}$ & CHK007b & MH123962 & - \\
\hline $\begin{array}{l}\text { 28/07/2014. Collector: J. Zapata, } \\
\text { L.Contreras-Porcia }\end{array}$ & CHK0008 & MH123963 & - \\
\hline $\begin{array}{l}\text { 28/07/2014. Collector: J. Zapata, } \\
\text { L.Contreras-Porcia }\end{array}$ & CHK0009/SGO168327 & MH123964 & MH124042 \\
\hline $\begin{array}{l}\text { 28/07/2014. Collector: J. Zapata, } \\
\text { L.Contreras-Porcia }\end{array}$ & CHK0010 & MH123965 & MH124044 \\
\hline $\begin{array}{l}\text { 28/07/2014. Collector: J. Zapata, } \\
\text { L.Contreras-Porcia }\end{array}$ & CHK0012 & MH123966 & MH124055 \\
\hline $\begin{array}{l}\text { 28/07/2014. Collector: } \\
\text { C.Lovazzano, F.Castañeda }\end{array}$ & CHK0013/SGO168328 & MH123967 & MH124045 \\
\hline $\begin{array}{l}\text { 28/07/2014. Collector: } \\
\text { C.Lovazzano, F.Castañeda }\end{array}$ & CHK0014/SGO168329 & MH123968 & MH124046 \\
\hline $\begin{array}{l}\text { 28/07/2014. Collector: J. Zapata, } \\
\text { L.Contreras-Porcia }\end{array}$ & CHK0017/SGO168330 & MH123969 & MH124047 \\
\hline $\begin{array}{c}\text { 28/07/2014. Collector: J. Zapata, } \\
\text { L.Contreras-Porcia }\end{array}$ & CHK0018/SGO168331 & MH123970 & MH124057 \\
\hline $\begin{array}{c}\text { 28/07/2014. Collector: J. Zapata, } \\
\text { L.Contreras-Porcia }\end{array}$ & CHK0021 & MH123971 & MH124036 \\
\hline $\begin{array}{l}\text { 28/07/2014. Collector: J. Zapata, } \\
\text { L.Contreras-Porcia }\end{array}$ & CHK0022 & MH123972 & MH124039 \\
\hline 28/07/2014.. Collector: J. Zapata, & CHK0023 & MH123973 & - \\
\hline
\end{tabular}




\begin{tabular}{|c|c|c|c|}
\hline L.Contreras-Porcia & & & \\
\hline $\begin{array}{c}\text { 28/07/2014. Collector: J. Zapata, } \\
\text { L.Contreras-Porcia }\end{array}$ & CHK0024/SGO168332 & MH123974 & MH124049 \\
\hline $\begin{array}{c}\text { 06/09/2013. Collector: J. Zapata, } \\
\text { F.Castañeda }\end{array}$ & CHK0025/SGO168333 & MH123975 & MH124050 \\
\hline $\begin{array}{l}\text { 28/07/2014. Collector: J. Zapata, } \\
\text { L.Contreras-Porcia }\end{array}$ & CHK0026 & MH123976 & - \\
\hline $\begin{array}{l}\text { 28/07/2014. Collector: J. Zapata, } \\
\text { L.Contreras-Porcia }\end{array}$ & CHK026b & MH123977 & - \\
\hline $\begin{array}{l}\text { 10/10/2013. Collector: C.Fierro- } \\
\text { F.Castañeda }\end{array}$ & CHK0028/SGO168334 & MH123978 & MH124051 \\
\hline $\begin{array}{l}\text { 28/07/2014. Collector: J. Zapata, } \\
\text { L.Contreras-Porcia }\end{array}$ & CHK0032 & MH123979 & MH124056 \\
\hline $\begin{array}{c}\text { 28/07/2014. Collector: J. Zapata, } \\
\text { L.Contreras-Porcia }\end{array}$ & CHK0033 & MH123980 & MH124052 \\
\hline $\begin{array}{l}\text { 28/07/2014. Collector: J. Zapata, } \\
\text { L.Contreras-Porcia }\end{array}$ & CHK0034 & MH123981 & MH124053 \\
\hline $\begin{array}{c}\text { 28/07/2014. Collector: J. Zapata, } \\
\text { L.Contreras-Porcia }\end{array}$ & CHK0037/SGO168335 & MH123982 & MH124054 \\
\hline $\begin{array}{l}\text { 28/07/2014. Collector: } \\
\text { C.Lovazzano- F.Castañeda }\end{array}$ & CHK0040/SGO168336 & MH123983 & MH124048 \\
\hline $\begin{array}{c}\text { 28/07/2014. Collector: J. Zapata, } \\
\text { L.Contreras-Porcia }\end{array}$ & CHK036o & MH123984 & - \\
\hline $\begin{array}{c}\text { 28/07/2014. Collector: J. Zapata, } \\
\text { L.Contreras-Porcia }\end{array}$ & CHK038o & MH123985 & - \\
\hline $\begin{array}{c}\text { 28/07/2014. Collector: J. Zapata, } \\
\text { L.Contreras-Porcia }\end{array}$ & CHK044o & MH123986 & - \\
\hline
\end{tabular}




\begin{tabular}{|c|c|c|c|}
\hline $\begin{array}{l}\text { 28/07/2014. Collector: J. Zapata, } \\
\text { L.Contreras-Porcia }\end{array}$ & CHK050o & MH123987 & - \\
\hline $\begin{array}{c}\text { 28/07/2014. Collector: J. Zapata, } \\
\text { L.Contreras-Porcia }\end{array}$ & CHK055o & MH123988 & - \\
\hline $\begin{array}{c}\text { 28/07/2014. Collector: J. Zapata, } \\
\text { L.Contreras-Porcia }\end{array}$ & CHK015v & MH123989 & - \\
\hline $\begin{array}{c}\text { 28/07/2014. Collector: J. Zapata, } \\
\text { L.Contreras-Porcia }\end{array}$ & CHK030L & MH123990 & - \\
\hline $\begin{array}{l}\text { 28/09/2014. Collector: J. Zapata, } \\
\text { L.Contreras-Porcia }\end{array}$ & CHK035o & MH123991 & - \\
\hline $\begin{array}{c}\text { 28/09/2014. Collector: J. Zapata, } \\
\text { L.Contreras-Porcia }\end{array}$ & CHK039o & MH123992 & - \\
\hline $\begin{array}{l}\text { 28/09/2014. Collector: J. Zapata, } \\
\text { L.Contreras-Porcia }\end{array}$ & CHK071o & MH123993 & - \\
\hline $\begin{array}{l}\text { 28/09/2014. Collector: J. Zapata, } \\
\text { L.Contreras-Porcia }\end{array}$ & CHK106o & MH123994 & - \\
\hline $\begin{array}{l}\text { 28/09/2014. Collector: J. Zapata, } \\
\text { L.Contreras-Porcia }\end{array}$ & CHK024v & MH123995 & - \\
\hline $\begin{array}{l}\text { 28/09/2014. Collector: J. Zapata, } \\
\text { L.Contreras-Porcia }\end{array}$ & CHK033v & MH123996 & - \\
\hline $\begin{array}{l}\text { 28/09/2014. Collector: J. Zapata, } \\
\text { L.Contreras-Porcia }\end{array}$ & CHK037L & MH123997 & - \\
\hline $\begin{array}{l}\text { 28/09/2014. Collector: J. Zapata, } \\
\text { L.Contreras-Porcia }\end{array}$ & CHK105o & MH123998 & - \\
\hline $\begin{array}{l}\text { 02/01/2014. Collector: J. Zapata, } \\
\text { L.Contreras-Porcia }\end{array}$ & ORB0004 & MH123999 & MH124058 \\
\hline 02/12/2013. Collector: J. Zapata, & $0011 / \mathrm{SGO} 168323$ & MH124000 & - \\
\hline
\end{tabular}


L.Contreras-Porcia

\begin{tabular}{|c|c|c|c|}
\hline $\begin{array}{c}\text { 02/01/2014. Collector: J. Zapata, } \\
\text { L.Contreras-Porcia }\end{array}$ & ORB0015 & MH124001 & - \\
\hline $\begin{array}{c}\text { 02/01/2014. Collector: J. Zapata, } \\
\text { L.Contreras-Porcia }\end{array}$ & ORB0016 & MH124002 & - \\
\hline $\begin{array}{c}\text { 28/09/2014. Collector: J. Zapata, } \\
\text { L.Contreras-Porcia }\end{array}$ & ORB0046 & MH124003 & - \\
\hline $\begin{array}{l}\text { 28/09/2014. Collector: J. Zapata, } \\
\text { L.Contreras-Porcia }\end{array}$ & ORB0061 & MH124004 & - \\
\hline $\begin{array}{c}\text { 28/09/2014. Collector: J. Zapata, } \\
\text { L.Contreras-Porcia }\end{array}$ & ORB0062 & MH124005 & - \\
\hline $\begin{array}{l}\text { 28/09/2014. Collector: J. Zapata, } \\
\text { L.Contreras-Porcia }\end{array}$ & ORB0064 & MH124006 & - \\
\hline $\begin{array}{c}\text { 28/09/2014. Collector: J. Zapata, } \\
\text { L.Contreras-Porcia }\end{array}$ & ORB0066 & MH124007 & - \\
\hline $\begin{array}{l}\text { 28/09/2014. Collector: J. Zapata, } \\
\text { L.Contreras-Porcia }\end{array}$ & ORB0063 & MH124008 & - \\
\hline $\begin{array}{c}\text { 28/09/2014. Collector: J. Zapata, } \\
\text { L.Contreras-Porcia }\end{array}$ & ORB0052 & MH124009 & - \\
\hline $\begin{array}{c}\text { 28/09/2014. Collector: J. Zapata, } \\
\text { L.Contreras-Porcia }\end{array}$ & ORB0075 & MH124010 & - \\
\hline $\begin{array}{c}\text { 28/09/2014. Collector: J. Zapata, } \\
\text { L.Contreras-Porcia }\end{array}$ & ORB0072 & MH124011 & - \\
\hline
\end{tabular}


Table S2. Specimen collection information and GENBANK accession numbers of sequences of COI and $r b c \mathrm{~L}$ used in Maximum Likelihood tree reconstruction to complement our data set (see Table S1). Specimens are in alphabetical order.

\begin{tabular}{|c|c|c|}
\hline Taxon & Collection location & $\begin{array}{l}\text { COI - GENBANK } \\
\text { Accession no. }\end{array}$ \\
\hline Bangia atropurpurea & " Devon, Sidmouth, UK & DQ442886 \\
\hline Bangia atropurpurea & Dorset, Kimmeridge, UK & DQ442887 \\
\hline Bangia fuscopurpurea & Rhode Island, Brenton Point., Newport, USA & JN028460 \\
\hline Bangia sp. 1BAN & $\begin{array}{l}\text { British Columbia, Whiffen Spit, Sooke Harbour, Vancouver Island, } \\
\text { Canada }\end{array}$ & JN028465 \\
\hline Bangia sp. 2BAN & Quebec, Escoumins (Rue des Pilotes), Canada & JN028476 \\
\hline Bangiales sp. HK-2011a & $\begin{array}{l}\text { British Columbia, Ramsey Island (beach on NW coast), Gwaii } \\
\text { Haanas, Canada }\end{array}$ & JN028481 \\
\hline Bangiales sp. HK-2011c & British Columbia, Ridley Island, Prince Rupert, Canada & JN028495 \\
\hline Boreophyllum birdiae & Newfoundland and Labrador, from Bonne Bay Station, Canada & JN028485 \\
\hline Fuscifolium sp. CHA & Región de Coquimbo, Choapa, Puerto Oscuro & KP781631 \\
\hline Porphyra corallicola & New Brunswick, Maces Bay, Bay of Fundy, Canada & JN028496 \\
\hline Porphyra dioica & Talmine, Sutherland, Scotland, UK & DQ191339 \\
\hline Porphyra sp. JB286 & Sussex, Bracklesham Bay, England, UK & DQ191335 \\
\hline Porphyra mumfordii & British Columbia, Bamfield, Bradys Beach, Canada & JN028502 \\
\hline Porphyra mumfordi & Región de Los Lagos Hueihue, Chiloé, Chile & KP781651 \\
\hline Porphyra mumfordi & Región de Los Ríos, Los Molinos, Valdivia, Chile & KP781682 \\
\hline Porphyra purpurea & New Brunswick, Richebucto Cape Breakwater, Canada & JN028518 \\
\hline Porphyra rosengurttii & Faroe Islands & AM943399 \\
\hline Porphyra sp. 1FIH & Chacao, Chiloe, Chile & JN028551.1 \\
\hline Porphyra sp. CHB & Región de Los Lagos, Cucao, Chiloé & KP781663 \\
\hline Porphyra sp. CHC & Región de Los Ríos, Playa Rosada, Valdivia, Chile & KP781684 \\
\hline Porphyra sp. CHC & Región de Valparaíso, Petorca, Salinas de Pullay & $\begin{array}{l}\text { KP781638/ } \\
\text { KP781639 }\end{array}$ \\
\hline Porphyra sp. CHC & Región de la Araucanía, Cautin, Cheuque & KP781643 \\
\hline Porphyra sp. CHC & Región de Los Ríos, Pichicuyin, Valdivia, Chile & $\begin{array}{l}\text { KP781644/ } \\
\text { KP781645 }\end{array}$ \\
\hline Porphyra sp. CHD & Región de Magallanes, Magallanes, Buque Quemado & KP781673 \\
\hline Porphyra sp. CHF & Región de Antofagasta, Antofagasta, Playa El Lenguado & $\begin{array}{l}\text { KP781562/ } \\
\text { KP781563 }\end{array}$ \\
\hline Porphyra sp. CHF & Región de Coquimbo, Elqui, Guanaquerillos & $\begin{array}{l}\text { KP781559/ } \\
\text { KP781564/ } \\
\text { KP781565 }\end{array}$ \\
\hline Porphyra sp. CHF & Región de Coquimbo, Caleta las Conchas, Choapa, Chile & KP781560 \\
\hline Porphyra sp. CHF & Región de Valparaíso, Quintay-Playa Chica, Valparaíso, Chile & KP781567 \\
\hline Porphyra sp. CHF & Región de Valparaíso, Playa Amarilla, Valparaíso, Chile & $\begin{array}{l}\text { KP781689/ } \\
\text { KP781647 }\end{array}$ \\
\hline Porphyra sp. CHF & Región de Valparaíso, Valparaíso, Curaumilla, Chile & $\begin{array}{l}\text { KP781674/ } \\
\text { KP781675/ } \\
\text { KP781691/ } \\
\text { KP781649 }\end{array}$ \\
\hline Porphyra sp. CHF & Región de Valparaíso, Valparaíso, Playa El Encanto, Chile & $\begin{array}{l}\text { KP781690/ } \\
\text { KP781692/ } \\
\text { KP781693 }\end{array}$ \\
\hline Porphyra sp. CHF & Región de Valparaíso, San Antonio, Punta de Tralca, Chile & $\begin{array}{l}\text { KP781568/ } \\
\text { KP781569/ } \\
\text { KP781570/ } \\
\text { KP781571/ } \\
\text { KP781572 }\end{array}$ \\
\hline Porphyra sp. CHF & Región de Valparaíso, San Antonio, Las Cruces, Chile & KP781573/ \\
\hline
\end{tabular}




\author{
Porphyra sp. CHF \\ Porphyra sp. CHF \\ Porphyra sp. CHF
}

Porphyra sp. CHF

Porphyra sp. FIH

Porphyra sp. FIH

Porphyra sp. FIH

Porphyra sp. FIH

Porphyra sp. FIH

Porphyra sp. FIH

Porphyra sp. FIH

Porphyra sp. FIH

Porphyra sp. FIH

Porphyra sp. FIH

Porphyra sp. FIH

Porphyra sp. FIH

Porphyra sp. HK-2011c

Porphyra sp. HK-2011d

Porphyra umbilicalis

Pyropia abbottiae

Pyropia acanthophora

Pyropia fallax

Pyropia fucicola

Pyropia gardneri

Pyropia kurogii

Pyropia leucosticta

Pyropia nereocystis

Pyropia nereocystis

Pyropia njordii

Pyropia njordii

Pyropia orbicularis
Región del Biobío, Concepción, Coliumo, Chile

KP781574

KP781584/

KP781585

KP781575

Región del Libertador General Bernardo O’Higgins, Cardenal Caro, Pichilemu, Chile

Región del Libertador General Bernardo O'Higgins, Cardenal Caro, La Boca, Chile

KP781677/

KP781694/

KP781678/

KP781695/

KP781680

Región de Valparaíso, Valparaíso, Playa El Encanto; Chile

Región de Los Lagos, Llanquihue, Metri, Chile

KP781693

KP781592/

KP781593/

KP781594/

KP781595/

KP781596

KP781597

KP781650/

KP781646

KP781653

KP781654

KP781655/

KP781656

KP781657/

KP781658/

KP781659/

KP781660/

KP781661

KP781686/

KP781688

KP781670/

KP781671

KP781672

KP781696/

KP7816797

KP781681

KP781641/

KP781642

HM917381.1

JN028798.1

JN028569

JN028597

JN222750

HQ969862

JN028614

HM915300

JN028655

JN028662

JN028685

HQ919419.1

JN028693

JN028690.1

KP781637/

Región de Valparaíso, Petorca, Salinas de Pullay, Chile

KP781637/ 
Pyropia orbicularis

Pyropia orbicularis

Pyropia orbicularis

Pyropia orbicularis

Pyropia orbicularis

Pyropia orbicularis

Pyropia orbicularis

Pyropia orbicularis

Pyropia orbicularis

Pyropia orbicularis

Pyropia orbicularis

Pyropia perforata

Pyropia sp. 1Cal

Pyropia sp. 1POR

Pyropia sp. 2Cal

Pyropia sp. 6POR

Pyropia sp. $\mathrm{CHH}$

Pyropia sp. CHI

Pyropia sp. CHI

Pyropia sp. CHJ

Pyropia sp. CHJ

Pyropia sp. CHJ

Pyropia sp. CHJ

Pyropia sp. CHJ

Pyropia sp. CHJ

Pyropia sp. CHJ

Pyropia sp. CHJ

Pyropia sp. CHJ

Pyropia sp. CHJ

Pyropia sp. CHJ

Pyropia sp. CHK

Pyropia sp. CHK
Región de Valparaíso, Maitencillo, Chile

KP781640

KF479515/

KF479507/

KF479516/

KF479502/

KF479503/

KF479504/

KF479505/

KF479506/

KF479508/

KF479509/

KF479512/

KF479513/

KF479514

Región del Maule, Duao, Curico, Chile

KP781576/

KP781577/

KP781578/

KP781579

Región del Maule, Constitución, Talca, Chile

KP781580/

KP781581/

KP781582/

KP781583

Región del Biobío, Lota, Concepción, Chile

KP781587

Región de Los Ríos, Calfuco, Valdivia, Chile

KP781589

Región de Los Ríos, Niebla, Valdivia, Chile

KP781591

Región de Los Lagos, Chonchi, Chiloé, Chile

Región de Los Lagos, Llanquihue, Puerto Montt-Estaquilla

KP781602

KP781652

KP781685/

KP781697

Región de Magallanes, Magallanes, Fuerte Bulnes $\quad$ KP781665/

KP781666/

KP781667

California, Montara Beach, USA

HQ919270.1

JN028786

British Columbia, Whiffen Spit, SookeHarbour, Vancouver Island,

JN028790

Canada

California, McAbee Beach, Monterey, USA

JN028791

Texas, South Jetty, Port Arkansas, USA

Región de Los Ríos, Valdivia, Niebla (Playa Grande)

Región de Arica y Parinacota, Arica, Playa Corazón, Chile

Región de Coquimbo, Elqui, Abalonera Chica, Chile

JN028792

KP781676

KP781561

KP781620/

KP781621/

KP781622

Región del Biobío, Coliumo, Concepción, Chile

Concepción, Lebu, Chile

KP781586

KP781588

KP781590

KP781687

KP781600

KP781662/

KP781648

KP781683

KP781586

KP781598

KP781601

KP781599

KP781566

KP781611/ 


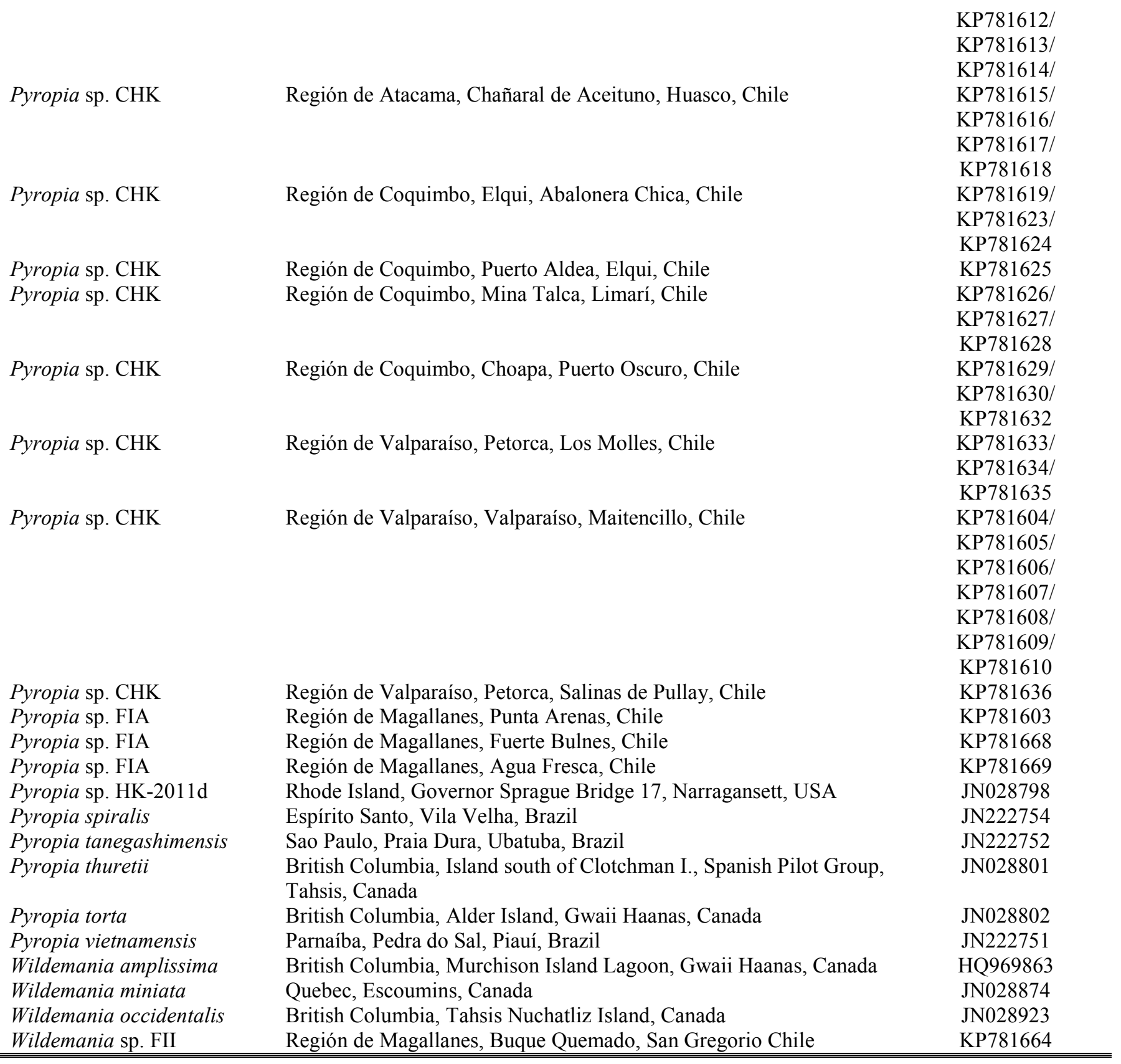




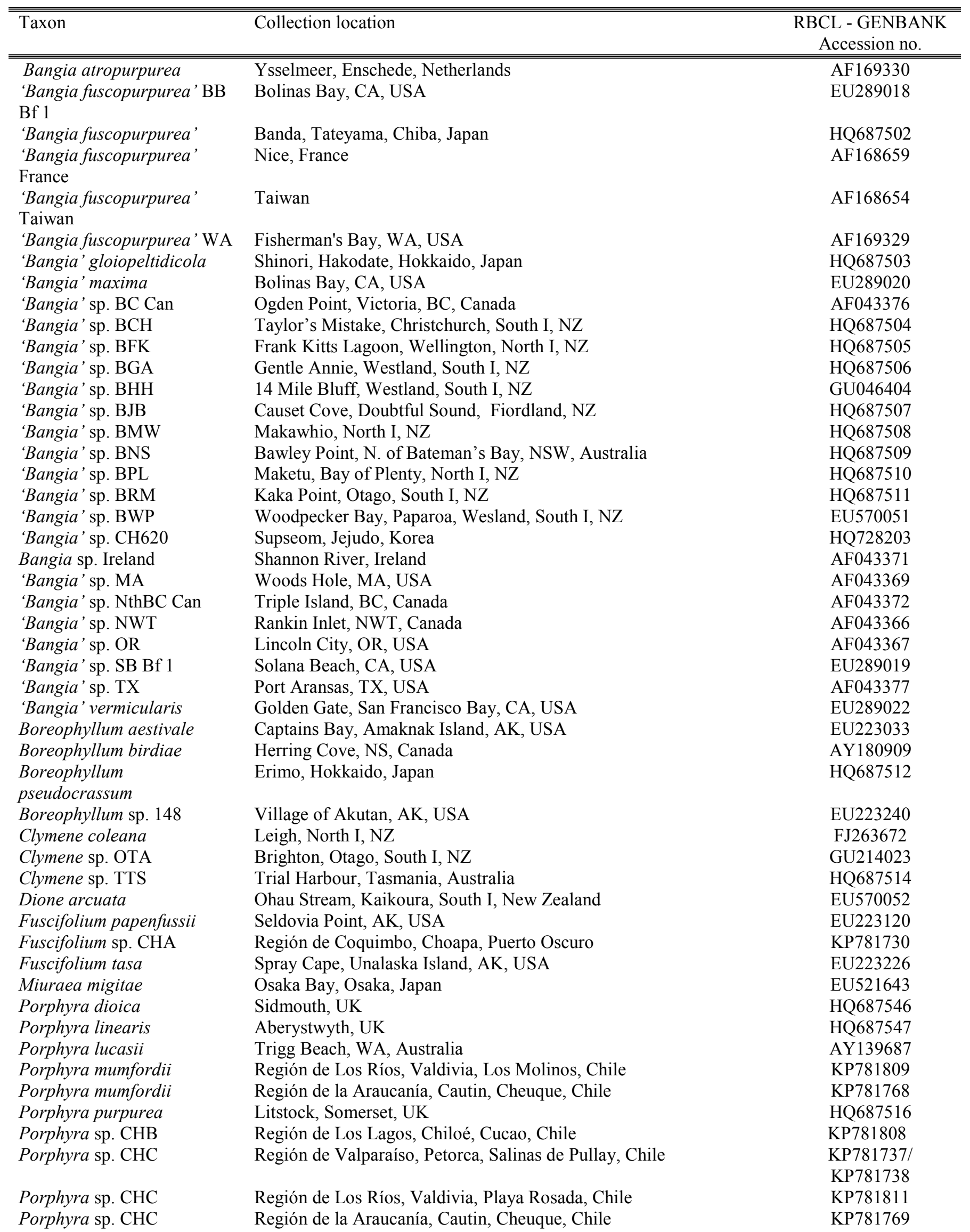


Porphyra sp. CHC

Porphyra sp. CHC

Porphyra sp. CHF

Porphyra sp. CHF

Porphyra sp. CHF

Porphyra sp. CHF

Porphyra sp. CHF

Porphyra sp. CHF

Porphyra sp. CHF

Porphyra sp. CHF

Porphyra sp. CHF

Porphyra sp. CHF

Porphyra sp. CHF

Porphyra sp. CHF

Porphyra sp. FIB

Porphyra sp. FIG

Porphyra sp. FIG

Porphyra sp. FIG

Porphyra sp. FIH Porphyra sp. FIH

Porphyra sp. FIH Porphyra sp. FIH Porphyra sp. FIH

Porphyra sp. FIH

Porphyra sp. FIH Porphyra sp. FIH Porphyra sp. FIH Porphyra sp. FIH
Región de Los Ríos, Valdivia, Pichicuyin, Chile

KP781770/

KP781771

Región de Atacama, Huasco, Los Burros, Chile

KP781705

Región de Antofagasta, Antofagasta, Playa El Lenguado,Chile

KP781699

Región de Coquimbo, Elqui, Guanaquerillos, Chile

KP781719/

KP781720

Región de Coquimbo, Elqui, Puerto Aldea, Chile

KP781723/

KP781724

KP781707/

KP781708

KP781731

KP781749/

KP781750

KP781751

Región del Libertador General Bernardo O’Higgins, Cardenal Caro, Pichilemu, Chile

Región del Libertador General Bernardo O'Higgins, Cardenal Caro, La Boca, Chile

KP781847/

KP781848/

HQ687552/

KP781849/

KP781850/

KP781854

Región del Biobío, Concepción, Coliumo, Chile

KP781764

Región de Valparaíso, Valparaíso, Playa Amarilla, Chile

KP781838

Región de Valparaíso, Valparaíso, Playa El Encanto, Chile

KP781839/

KP781844/

KP781846

Región de Valparaíso, Valparaíso, Curaumilla, Chile

KP781840/

KP781841/

KP781842/

KP781843

Falkland Is

Weddell Inn, Weddell Is, Falkland Is

Región de Magallanes, Magallanes, Buque Quemado, Chile

Región de Magallanes, Magallanes, Fuerte Bulnes, Chile

Región de la Araucanía, Cautin, Cheuque, Chile

Región de Los Lagos, Llanquihue, Metri, Chile

GU165840

GU165885

KP781819

KP781828/

KP781832

KP781767

KP781774/

KP781775/

KP781776/

KP781777/

KP781778/

KP781779/

KP781780/

KP781781

KP781787

KP781782

KP781792

KP781794/

KP781795

KP781798

KP781799

KP781800

KP781801/

KP781802/

KP781803/

KP781804/ 
Porphyra sp. FIH

Porphyra sp. FIH

Porphyra sp. FIH

Porphyra sp. FIH

Porphyra sp. FIH

Porphyra sp. GDM Porphyra sp. GRB108 Porphyra sp. GRB145

Porphyra sp. GRB178

Porphyra sp. GRB287

Porphyra sp. GRB368 Porphyra sp. GRB488

Porphyra sp. JBCH26A

Porphyra sp. LGD

Porphyra sp. MTR

Porphyra sp. OSK

Porphyra sp. SBA

Porphyra sp. SIR

Porphyra sp. TAS

Porphyra sp. WLR

Porphyra sp. ZBS

Porphyra sp. ZCE

Porphyra sp. ZDR

Porphyra sp. ZGR

Porphyra sp. ZIR

Porphyra sp. ZPP

Porphyra sp. ZSM

Porphyra umbilicalis

Pyropia abbottiae

Pyropia acanthophora

Pyropia aeodis

Pyropia brumalis

Pyropia cf crassa

Pyropia cf pseudolinearis

Pyropia cf thuretii

Pyropia cinnamomea

Pyropia columbina

Pyropia conwayae

Pyropia dentata

Pyropia denticulata

Pyropia fallax

Pyropia fucicola
Región de Los Ríos, Valdivia, Playa Rosada, Chile

KP781805

KP781814/

KP781816

KP781829/

KP781830/

KP781834/

KP781835

KP781836

KP781851/

KP781852/

KP781853

GU046415

GU214021

HQ687548

HQ687549

HQ687550

HQ687551

GU046405

HQ687552

GU046409

HQ687553

HQ687554

GU046414

GU046417

GU046427

GU165837

HQ687555

GU046424

GU046425

HQ687556

GU214022

HQ687557

HQ687558

HQ687559

EU223024

HQ605695

GU165843

EU223038

HQ687518

EU223172

HQ687519

EU521637

GU046423

EU223045

HQ687520

HQ687521

GU319865

EU223088 
Pyropia gardneri AK

Pyropia gardneri

Pyropia haitanensis

Pyropia hiberna

Pyropia hollenbergii

Pyropia ishigecola

Pyropia kanakaensis

Pyropia katadae Japan

Pyropia katadae Korea

Pyropia kinositae

Pyropia koreana

Pyropia kuniedae

Pyropia kurogii AK

Pyropia kurogii Japan

Pyropia lacerata

Pyropia leucosticta

Pyropia moriensis

Pyropia nereocystis

Pyropia onoi

Pyropia orbicularis

Pyropia orbicularis

Pyropia orbicularis

Pyropia orbicularis

Pyropia orbicularis

Pyropia orbicularis

Pyropia orbicularis

Pyropia orbicularis
Northeast Ushagat Island, AK, USA

EU223096

Caminitos (Cabo Punta Banda), Baja California, Mexico

HQ687522

Yuge, Ehime, Japan

AB 118585

foot of 15th Street, Pacific Grove, Monterey County, CA, USA

GU319866

Agua Verde, Baja California Sur, Mexico

HQ687523

Yoshio, Katsuura, Chiba, Japan

HQ687524

between Makah Bay and Sekui, Olympic Peninsula, WA, USA

EU223099

Ise, Mie, Japan

HQ687525

Pohang, Gyeongsangbukdo, Korea

HQ728199

Arito, Suttu, Hokkaido, Japan

EU521641

Ohori, Gangwondo, Korea

HQ728198

Sachon, Namhae, Gyeongsangnamdo, Korea

HQ728200

Sandy Beach, Sitka, AK, USA

EU223105

Utoro, Hokkaido, Japan

HQ687526

Shirahama, Chiba, Japan

HQ687527

Sidmouth, UK

HQ687528

Otaru, Hokkaido, Japan

EU521645

Northeast Ushagat Island, AK, USA

EU223117

Mori, Hokkaido, Japan

HQ687529

Región de Valparaíso, Petorca, Salinas de Pullay

KP781735/

KP781736/

KP781739

KF479481/

KF479482/

KF479484/

KF479485/

KF479486/

KF479488/

KF479489/

KF479490/

KF479491/

KF479492/

KF479497/

KF479498/

KF479499

KP781752/

KP781753/

KP781754/

KP781755/

KP781756/

KP781757

KP781758/

KP781759/

KP781761/

KP781762/

KP781763

Región del Biobío, Concepción, Cocholgue

KP781765

Región del Biobío, Concepción, Lota

KP781766

Región de Los Ríos, Valdivia, Calfuco

KP781772

Región de Los Lagos, Chiloé, Playa Mar Brava

KP781788 
Pyropia orbicularis

Pyropia orbicularis

Pyropia orbicularis

Pyropia orbicularis

Pyropia orbicularis

Pyropia orbicularis

Pyropia orbicularis

Pyropia pendula

Pyropia perforata

Pyropia pseudolanceolata

Pyropia pseudolinearis

Japan

Pyropia pseudolinearis

Korea

Pyropia pulchella

Pyropia rakiura

Pyropia saldanhae

Pyropia seriata

Pyropia smithii

Pyropia sp. 480

Pyropia sp. 485

Pyropia sp. 523

Pyropia sp. 551

Pyropia sp. AKL

Pyropia sp. Antar68

Pyropia sp. CHG

Pyropia sp. $\mathrm{CHH}$

Pyropia sp. $\mathrm{CHH}$

Pyropia sp. CHI

Pyropia sp. CHI

Pyropia sp. CHJ

Pyropia sp. CHJ

Pyropia sp. CHJ

Pyropia sp. CHJ

Pyropia sp. CHJ

Pyropia sp. CHJ

Pyropia sp. CHJ

Pyropia sp. CHK
Región de Los Lagos, Chiloé, Chonchi

KP781791

Región de Los Lagos, Llanquihue, Punta Corona

KP781796

Región de Los Lagos, Llanquihue, Puerto Montt-Estaquilla

KP781797

Región de Los Lagos, Chiloé, Achao, Punta Palqui

KP781806

Región de Los Ríos, Valdivia, Playa Rosada

KP781812

Región de Los Ríos, Valdivia, Playa Rosada

KP781813

KP781825/

KP781827

Calerita, Baja California Sur, Mexico

HQ687530

EU223127

Lighthouse, Del Norte County, CA, USA (rbcL)

Harling Point, Victoria, BC, Canada

EU223145

Choshi, Chiba, Japan

HQ687531

Dokdo, Gyeongsangbukdo, Korea

HQ728196

Waihau Bay East, North I, NZ

HQ687532

EU521646

GU165838

HQ687533

EU223224

GU319867

GU319868

GU319869

GU319870

GU046403

HQ605698

KP781837

KP781845

KP781784

KP781698

KP781713/

KP781714/

KP781715

KP781760

KP781773

KP781783

KP781785/

KP781786

KP781789/

KP781790/

KP781807

KP781810

KP781815

KP781701/

KP781702/

KP781703/

KP781704 
Región de Magallanes, Magallanes, Fuerte Bulnes

KP781822

KP781831

Región de Magallanes, Magallanes, Agua Fresca

KP781833

Top Island, Port Stanley, East Falkland, Falkland Is.

GU046422

East Loafers, Sea Lion I, Falkland Is.

GU046406

Región de Magallanes, Magallanes, Fuerte Bulnes

KP781793/

KP781823/

KP781826

Top Island, Port Stanley, East Falkland, Falkland Is.

GU046408

Avon/Heathcote Estuary, Christchurch, South I, NZ

GU165841

Faru de San Miguel, Baja California, Mexico

HQ687536

Parnaiba, Piaui, Brazil

HQ605697

Northwest Bay, Manawa Tawhi, Three Kings Islands, NZ

HQ687537

Ocean View, Kaikoura, South I, NZ

GU046410

Henderson Point, North I, NZ

HQ687538

Curio Bay, Southland, South I, NZ

HQ687539

Ocean View, Kaikoura, South I, NZ

GU046411

Brighton, Otago, South I, NZ ( 2 collections, 11 Feb 1997 nrSSU \&

GU046421 21 May $2001 \mathrm{rbcL}$ )

Campbell Point, Otago, South I, NZ

HQ687540 
Pyropia sp. TCH

Pyropia sp. WRO

Pyropia sp. ZLI

Pyropia spiralis

Pyropia suborbiculata

Pyropia tanegashimensis

Pyropia tenera

Pyropia tenuipedalis

Pyropia torta

Pyropia vietnamensis

Pyropia virididentata

Pyropia yezoensis

Wildemania amplissima

Wildemania norrisii

Wildemania occidentalis

Wildemania schizophylla

Wildemania sp. Antar23

Wildemania sp. FII

Wildemania sp. FII

Wildemania sp. HM080

Wildemania variegata $\mathrm{AK}$

Wildemania variegata Japan
Torias Corner, Stewart I, NZ

GU046418

Punakaiki, Westland, South I, NZ

HQ687541

Paternoster, South Africa

GU165839

Vila Velha, Espírito Santo, Brazil

HQ605696

Wonsando, Chungchungnamdo, Korea

HQ728201

Iseki, Tanegashima, Kagoshima, Japan

HQ687542

Kawaura, Kumamoto, Japan

HQ687543

Urayasu, Chiba, Japan

EU521649

EU223236

HQ687544

EU521650

HQ728197

HQ687560

EU223212

EU223118

GU319871

HQ605700

Admiralty Bay, King George Island, South Shetlands Archipelago, Antarctica

Región de Magallanes, Magallanes, Buque Quemado

KP781817/

KP781818/

KP781820

Hill cove kelp forest west of jetty, West Falkland, Falkland Is.

GU165883

HQ728202

EU223237

Kagamil Island, AK, USA

GU046430 
Table S3. Mean genetic distances calculated within- and between species for Pyropia sp. CHJ, Pyropia sp. CHK and Pyropia orbicularis for the COI. Genetic distances calculated within species are noted in bold along the diagonal. Genetic distances calculated between species pairs are noted below the diagonal. Sequences obtained in Maitencillo during this work were completed by the ones already available in Guillemin et al. (2016).

\begin{tabular}{cccc}
\hline & Pyropia $\mathrm{sp}$. CHJ & Pyropia orbicularis & Pyropia $\mathrm{sp}$. CHK \\
\hline Pyropia sp. CHJ & $\mathbf{0 . 0 0 8}$ & & \\
Pyropia orbicularis & 0.073 & $\mathbf{0 . 0 0 6}$ & \\
Pyropia sp. CHK & 0.038 & 0.063 & $\mathbf{0 . 0 0 1}$ \\
\hline
\end{tabular}

